\title{
Joanna RYBOWSKA
}

Uniwersytet Łódzki

\section{MAGIA I RELIGIA W ŚWIECIE STAROŻYTNYCH GREKÓW (ZARYS PROBLEMATYKI)}

\author{
MAGIC AND RELIGION IN THE ANCIENT GREEK WORLD
}

In the works of anthropologists, ethnologists and sociologists of the $19^{\text {th }}$ and $20^{\text {th }}$ centuries, we may notice their efforts to distinguish magic, on the one hand, from religion, and on the other, from science. One of the criteria, which set the boundaries between these field was the way, in which a community understood god/divinity. This, among others, enabled the identification of the three 'ideal stages' in the development of human culture: magical, religious and metaphysical-philosophical. This article is an attempt to analyse to what extent modern definitions of religion and magic can be applied in regard of ancient Greek culture. The surviving literary sources and other artefacts, which provide us with information on this culture, suggest that these stages, distinguished by modern researchers, never seemed to exist in 'pure form' in ancient Greek culture, but rather they intermingled and, at times barely noticeably, switched from one stage to another. Religion, magic and science not only functioned side-by-side, but they permeated and complemented each other.

Keywords: Greek magic, religion, magicians, purifiers, beggar-priests, seers, charlatans, curse tablets (katadesmoi)

Magia i praktyki magiczne, podobnie zresztą jak religia, należą do dziedzin, których zdefiniowanie nie należy do rzeczy łatwych ${ }^{1}$. Problem pogłębia się jeszcze bardziej, gdy próbujemy wyznaczyć precyzyjną granicę między religią

${ }^{1} \mathrm{Na}$ temat prób zdefiniowania pojęcia magii i religii $c f$. Gordon 1987: 59-95; Garcia-Teijeiro 1993: 123-138; Cunningham 1999: passim; Sieradzan 2005: 13-50; Buchowski 2005: 57-67. Cf. Szyjewski 2008: 37: „Pytanie, czym jest religia należy więc do najtrudniejszych zagadnień humanistyki światowej i stupięćdziesięcioletnie wyniki religioznawców nie zostały dotąd uwieńczone powodzeniem pozwalającym na stuprocentowo pewną odpowiedź. [...] Najczęściej jako punkt wyjścia przyjmuje się definicję religii Tielego-Söderbloma”. O wielorakim znaczeniu magii $c f$. Sieradzan 2011: 102: „Magią jest każda świadoma działalność człowieka mająca cel intencjonalny. Jako taka może ona mieć dwa aspekty: ceremonialny, w którym człowiek sam siebie nazywający 
a magią. W XIX i XX wieku, w pracach antropologów², etnologów i socjologów, obserwować możemy próby oddzielenia magii od religii z jednej strony, a od nauki z drugiej, jednakże wysiłki tych badaczy nie przyniosły zadawalających rezultatów ${ }^{3}$. W praktyce, badania te skupiały się na poszukiwaniu różnego rodzaju wyróżników służących do wyznaczenia limesów, przy pomocy których można by wyodrębnić wszystkie te dziedziny ${ }^{4}$.

$\mathrm{W}$ artykule tym będziemy analizowali, na ile te wyodrębnione przez badaczy granice znajdują swoje odniesienie do magii i religii starożytnych Greków. Jednym z wyznaczników był sposób, w jaki dana społeczność pojmowała boga/ bóstwo. Na tej m.in. podstawie, w rozwoju kultury ludzkiej wyróżniono trzy „,idealne etapy": 1) magiczny, 2) religijny, 3) metafizyczno-filozoficzny ${ }^{5}$.

Zachowane źródła pisane i inne artefakty, na podstawie których możemy cokolwiek powiedzieć o kulturze starożytnych Greków uzmysławiają nam, że wyżej wymienione etapy nigdy nie występowały w niej w ,idealnie czystej postaci”, a raczej przemieszanej i płynnej, przechodząc - czasami ledwie zauważalnie - jeden w drugi. Religia, magia i nauka nie tylko funkcjonowały obok siebie, ale wzajemnie się przenikały i uzupełniały. Parry, który przyjmował szerokie znaczenie pojęcia magii antycznej, uznawał ją za „wodę na młyn wielu dyscyplin: historii, teologii, antropologii, nauki, krytyki literackiej, psychologii i każdej innej formalnej organizacji ludzkiego doświadczenia". Przychylamy się do poglądu Parryego z jednym małym zastrzeżeniem - tą „,wodą na młyn” była religia, której towarzyszyły rytuały o charakterze religijno-magicznym. Jak słusznie akcentuje to Biernat, ,dla Greków pojęcie magii (nazwanej często innym słowem lub nienazwanej wcale) miało charakter wyłącznie normatywny. Nie wskazywało więc na zjawiska, których istoty nie dałoby się ostatecznie sprowadzić do religii. Magia nie była czymś sui generis"7. Uznawano ją podobnie jak religię za rzecz świętą

(lub nazywany) magiem, magiem-szamanem wykonuje ceremonię nastawioną na osiągnięcie określonego praktycznego celu (na przykład wyleczenia pacjenta), oraz metaforyczny, kiedy to filozof, artysta (poeta, śpiewak i im podobny) albo polityk posługuje się sztuką słowa, mając również na celu osiągnięcie określonego praktycznego celu «zaczarowanie» umysłu słuchacza, aby skłonić go do przyjętego przez siebie punktu widzenia".

${ }_{2}$ Cf. Jerzak-Gierszowska 1995: passim. (Książka prezentuje teorie magii i religii klasyków antropologii).

${ }^{3}$ Cf. Malinowski 1990: passim. Contra: Sieradzan 2005: passim; Buchowski 2005: 57-67.

${ }^{4}$ Książka antropologa Tambiaha (2007: passim) w całości została poświęcona kwestii wytyczenia granic między magią, religią i nauką.

${ }^{5}$ Cf. Buchowski 1986: 68.

${ }^{6}$ Cyt. za: Sieradzan 2005: 102.

${ }^{7}$ Cyt. za: Biernat 2013: 28. Podobne stanowisko zajmują Sieradzan 2005: 89: „Zarówno magia, jak i religia wzajemnie się przenikają w wielu kulturach tubylczych, tak jak niegdyś przenikały się na przykład w Babilonii czy w Egipcie, a później w Grecji”. Trzcionkowski 2013: 333: „Nie powinniśmy zatem przeciwstawiać «magii» i «religii», lecz opisywać płynne spektrum zachowań i wyobrażeń, których wspólnym prototypem jest potrzeba nawiązania komunikacji z istotami nadprzyrodzonymi”. Lengauer 1994: 137: ,[...] praktyki magiczne i obrzędy apotropaiczne występo- 
(hierà mageía), a magów za ludzi pobożnych (eusebés) i świątobliwych (hosioi) ${ }^{8}$. W przekonaniu wielu Hellenów zarówno kapłan, jak i mag potrafili w odpowiedni sposób nawiązać kontakt z bogami, znajdowali się więc bliżej bogów niż zwykli śmiertelnicy. Jak będziemy się mogli jeszcze o tym przekonać w dalszej części artykułu, w starożytnej Grecji mianem magów określano różnego rodzaju specjalistów religijnych.

Całkowicie podzielamy opinię tych badaczy, którzy wskazują, że rozważanie różnic dzielących magię od religii (nie tylko w odniesieniu do kultury Hellenów) należy uznać za „roztrząsanie sztucznego problemu, powstałego w wyniku definiowania religii, wychodzącego od idealnego wzorca chrześcijaństwa"9 lub „ułudę w wielorakim sensie”10. Nie sposób bowiem „wyznaczyć precyzyjnej granicy między religią a magią (nie wiadomo, czy taka granica w ogóle istnieje), a jeśli tak, to ma ona charakter liminalny" "11. Według skrajnego stanowiska Versnela „ani magia, ani religia nie istnieją. Istnieją tylko nasze definicje tych pojęć" "12; dodajmy - definicje, których wciąż poszukujemy.

Praktyki religijno-magiczne starożytnych Greków odgrywały znaczącą rolę nie tylko podczas uroczystości religijnych, ale towarzyszyły im również $\mathrm{w}$ wielu sferach życia codziennego, wpływały także znacząco na rozwój nauki ${ }^{13}$.

Umiejętności Asklepiadów, kapłanów udzielających porad i leczących ludzi w Asklepiejonach, wynikały zarówno ze znajomości sztuki lekarskiej, jak i praktyk religijno-magicznych związanych z kultem boga Asklepiosa ${ }^{14}$. Strabon i Pliniusz Starszy utrzymują, że sam Hippokrates miał korzystać z zapisków na wotach inskrypcyjnych, jakie znajdowały się w Asklepiejonie w mieście Astypalea na Kos. To dzięki nim miał on nauczyć się stosować dietę w terapii, jak utrzymuje Strabon, lub stworzyć nową gałąź medycyny, zwaną „kliniczną”, jak

wały w kulcie greckim, pobożność polegała także na spełnianiu i takich obrzędów, magia wchodziła w zakres religii...".

${ }^{8}$ Wypustek 2001: 37.

${ }^{9}$ Cyt. za: Pettersson 1957: 119; $c f$. Kracik 2012: passim.

${ }^{10}$ Cyt. za: Buchowski 2005: 57.

${ }^{11}$ Cf. Sieradzan 2005: 13-14. Ługiewicz 2001: 17: „[...] magia nie może istnieć bez religii, a religia bez magii”. Lévi-Strauss 2001: 294: „Nie ma religii bez magii, tak jak nie ma magii nie zawierającej przynajmniej odrobiny religii”. Spostrzeżenie to może być odniesione nawet do najwyższych form religii, bowiem i w nich tkwi duży ładunek magii. Bliski jest nam również pogląd i Teijeiro (1993: 138), która uznaje, że „aby właściwie zrozumieć religię, musimy wziąć pod uwagę magię i vice versa".

${ }^{12}$ Cyt. za: Versnel 1991: 177. Cf. również Luck 1985: 2: „Trudno powiedzieć, co odróżnia religię od magii”. Sieradzan 2011: 86: „Skoro [...] dla Greków ofiara i modlitwa były właściwie jedynymi formami kontaktu z bóstwem, a jedną i drugą wykorzystywano również w celach magicznych, to nie sposób wytyczyć jasnej linii oddzielającej grecką «religię» od greckiej «magii»".

13 Cyt. za: Versnel 1991: 177.

${ }^{14} \mathrm{O}$ funkcjonowaniu Asklepiejonów na przykładzie sanktuarium w Epidauros $c f$. Przybyłek 2011: 105-118. 
twierdzi z kolei Pliniusz ${ }^{15}$. Jeśli nawet mamy do czynienia w tym konkretnym przypadku jedynie z legendą, to nie sposób zaprzeczyć, że słynni lekarze praktykowali w szpitalach mieszczących się przy świątyniach boga i korzystali ze zgromadzonych tam inskrypcji. $Z$ tym mieszczącym się w Pergamonie związany był jeden z najwybitniejszych lekarzy, Galen. Dzięki jego świadectwu możemy zrozumieć, po pierwsze, jak dalece medycyna była powiązana i z magią, i religią, a po drugie, że Grecy ufali lekarzom-kapłanom i bogu Asklepiosowi bardziej niż jakiemukolwiek ,świeckiemu lekarzowi”:

Tak więc widzimy u nas, w Pergamonie, jak leczeni przez boga [Asklepiosa] są mu posłuszni, nawet gdy im często wydaje polecenie, by przez kolejnych piętnaście dni niczego zgoła nie pili; lekarzowi nigdy by w tym nie byli posłuszni. Dla bezwarunkowego posłuszeństwa wobec wszystkich tego rodzaju zaleceń ma bardzo wielkie znaczenie, by chory był głęboko przekonany, iż zostanie mu udzielona skuteczna pomoc ${ }^{16}$.

W wielu kulturach starożytnych „,nie istniały sztywne granice między magią, cudem czy medycyną"17. Przedstawiciele medycyny naukowej, jaką w Helladzie zapoczątkował Hippokrates, a kontynuowali ją jego następcy, podnosili co prawda głosy sprzeciwu wobec metod leczenia specjalistów religijno-magicznych, ale do końca trwania starożytności ludność korzystała z usług tych ostatnich. Medycyna jako nauka kwitła, dokonywano ważnych odkryć, a ludzie podążali jak przed wiekami jako błagalnicy do Asklepiejonów oraz zwracali się ze swymi dolegliwościami do znachorów i magów. Prawdziwą medycyną zajmowały się elity, i one były nią zainteresowane. Warto również zwrócić uwagę na fakt, że nawet przedstawiciele medycyny naukowej nie występowali przeciwko religii. Od wezwania bogów na świadków rozpoczynała się przysięga starożytnych medyków, ,,spadkobierców" Hippokratesa, lekarza i kapłana ${ }^{18}$.

„Filozofowie i prekursorzy nauki nie wykluczali religii jako sprzecznej czy niezgodnej z ich wiedzą. Boskość natury była przez Greków traktowana jako oczywista" ${ }^{19}$. Żaden z jońskich filozofów przyrody nie utrzymywał, że bogów/ boga nie ma; w zaprezentowanych przez nich koncepcjach teologicznych bogowie stali się częścią natury i kosmosu ${ }^{20}$. Pierwszy z wielkich Milezyjczyków Tales, chociaż twierdził, że zasadą wszechświata (arché) była woda i była ona „tym,

${ }^{15}$ Podaję za: Wiszowata 2012: 153.

${ }_{16}$ Galen, Komentarze do Epidemii Hippokratesa, przeł. Bednarczyk 1992: 88.

${ }^{17}$ Cyt. za: Cotter 1995: 5.: , ,...] the populace of antiquity, no firm lines divided magic from miracle or medicine".

${ }^{18}$ Cf. Rybowska 2017: 402.

${ }^{19}$ Cyt. za: Tambiah 2007: 22. Cf. Jamblich (Gajda-Krynicka 1993: 3): „Jest zwyczajem wszystkich ludzi roztropnych przy każdym przedsięwzięciu związanym z filozofią przywołać na pomoc boga; a zatem tym bardziej godzi się to uczynić, gdy chodzi o tę filozofię, która słusznie i sprawiedliwie wzięła miano od boskiego Pitagorasa. A ponieważ wzięła ona swój początek od bogów, nie wolno wręcz podejmować prób opisania jej inaczej, jak tylko z bogów pomocą".

${ }^{20}$ Contra: Szczerba 2014: 33-34. Cf. Gajda 1986: 5-76. 
z czego są wszystkie byty, z czego wszystko się wywodzi i do czego wszystko powraca po swym zniszczeniu, czego substancja pozostaje, lecz właściwości ulegają zmianie”, to przyjmował jednocześnie, że „wszystko jest pełne bogów”21. Anaksymander uważał apeiron za boga, ,podobnie można powiedzieć, że powietrze i Logos - zasady Anaksymenesa i Heraklita - posiadały prerogatywy bogów: suwerenność, mądrość i nieograniczoność. Stworzyli oni odrębne od mitologicznego, względnie abstrakcyjne pojęcie boskości, które być może wpłynęło m.in. na chrześcijańskie przekonanie o boskiej obecności w człowieku i w fizycznym świecie, a na pewno wpłynęło na światopogląd panteistyczny"22. W świecie starożytnych Greków, gdzie religia była wszechobecna, nie było czymś dziwnym ani rzadko spotykanym, aby wieszczek, wędrujący kapłan czy mag był jednocześnie poszukującym nieśmiertelności filozofem. To współczesna nauka nie uznaje takich połączeń. Miłośnik mądrości, który wieszczy, przepowiada, udziela porad i dokonuje cudów? Filozof, którego uznaje się za „boskiego mędrca” czy też „boskiego męża” i utrzymuje, że po śmierci stał się bogiem? Tego nie da się pogodzić23. „Opowieści tych zazwyczaj nie traktuje się poważnie. Ze względu na dominujące wśród naukowców scjentystyczne pojmowanie filozofii, wyrzuca się egzystencjalno-religijny aspekt nauczania presokratyków poza nawias ich filozofowania, traktując jako «strategię marketingową» bądź też «naiwność» myślenia mitologiczno-magicznego. Czy słusznie? [...] Może jednak soteriologiczny składnik filozofii przedsokratejskiej trzeba traktować z pełną powagą, jako integralną część tego typu filozofowania?"24. Na tak sformułowane przez Jastrzębskiego pytanie, udzielamy wraz z nim odpowiedzi twierdzącej. Powyższe uwagi mogą być odniesione nie tylko do filozofów określanych mianem presokratyków. Pitagoras, Empedokles, Sokrates, którzy poszukiwali innego wymiaru bóstwa niż ten, jaki obowiązywał w tradycyjnie pojmowanej therapeia theō ${ }^{25}$, łączyli w nowatorski

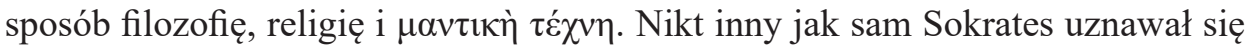
za „sługę boga” Apollona, najwyżej ceniąc wyrocznie tego boga.

Głębokie przekonanie Greków o realności bogów/daimones i ich aktywności w świecie oraz pragnienie nawiązania z nimi komunikacji, służyły rozwojowi tak praktyk religijnych, magicznych, jak i wielu innych dziedzin kultury starożytnych Hellenów. Bez względu na to, czy Grek prosił siły nadprzyrodzone o rzeczy dobre,

${ }^{21}$ Fr. A2, A22. Cf. Aetius, Placita philosophorum, I, 7, 11 (Leśniak 1972: 145): „Tales twierdził, że rozumem świata jest bóg, a także, iż ogół rzeczy jest ożywiony i pełen demonów; że właściwie przez elementarną wilgoć przenika do wewnątrz boska siła i porusza je".

${ }^{22}$ Cyt. za: Angutek, http://www.nowakrytyka. pl/spip.php?article303 [data dostępu 8.11.2015].

${ }^{23}$ Cyt. za: Sieradzan 2011: 99: „Presokratyków takich jak Pitagoras, Empedokles czy Parmenides jedni uważają za mędrców bądź filozofów, inni za szamanów lub magów. Badacze religii greckiej wolą w nich widzieć raczej magów-szamanów niż filozofów, za jakich uznają ich historycy filozofii. Z kolei uczeni widzą w nich prekursorów nauki: Pitagorasa uważa się za twórcę matematyki, a Empedoklesa za twórcę retoryki”.

${ }^{24}$ Cyt. za: Jastrzębski 2014: 12.

${ }^{25}$ O znaczeniu tego terminu $c f$. Rybowska 2017: 11. 
czy też złe, to wierzył, że skuteczność tej prośby jest uzależniona od skrupulatnego wypełnienia rytuału, jaki umożliwiał nawiązanie łączności z bóstwem ${ }^{26}$. Rytuały te służyły ustanawianiu i podtrzymywaniu harmonii między bogami a ludź$\mathrm{mi}^{27}$, a jest to, jak słusznie podkreśla Bremmer, fundamentalny element religii greckiej $^{28}$. Ponieważ wierzono, że umiejętności „religijno-magiczne” pochodzą od bogów, dlatego też funkcje pośredników, którzy umożliwiali kontakty pomiędzy ludźmi a bogami pełnili różnego rodzaju specjaliści religijni, znawcy sacrum.

Słowo magia (łac. magia; gr. $\mu \alpha \gamma \varepsilon i ́ \alpha$ ) pochodzi od staroperskiego rzeczownika maguš. Badacze, którzy dogłębnie przebadali znaczenie tego terminu, wskazują na jego podwójne znaczenie. $Z$ jednej strony oznaczał on perskich kapłanów Zaratustry, wyznawców zaratusztrianizmu, z drugiej przerażającego czarodzieja,

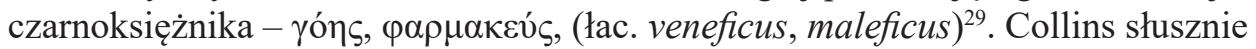
przyjmuje, że grecki termin mageía odnosił się do aktywności mágos. Problem polega jednak na tym, że nie wiemy, jakiego rodzaju aktywności pierwotnie dotyczy ${ }^{30}$. Pomimo to spora grupa badaczy uznaje, że - w porównaniu chociażby z wieszczkiem - mágos miał na ogół pejoratywne znaczenie. My, podobnie jak Betegh, nie wykluczamy, że „termin mágos w grece był początkowo neutralnym albo wręcz pozytywnym środkiem określenia oraz samookreślenia, tak jak $k a-$ thartés i agýrtes. Jako samookreślenie termin ten pozwalał również na przypisanie sobie autorytetu perskich kapłanów i dopiero później, poprzez rozmaite ataki rozpoczynające się od Heraklita, otrzymał negatywne konotacje"31.

Jeśli prześledzimy najstarsze, dostępne nam źródła greckie, które wzmiankują o magoi, to wynika z nich jasno, że wskazują one na pewnych specjalistów od

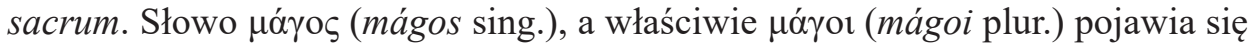
po raz pierwszy u Heraklita na określenie jakiś mystów, uczestników tajemnych obrzędów. Pod koniec V w. słowo magoi odnajdujemy na papirusie z Derveni, ponownie $\mathrm{w}$ związku z misteriami, najprawdopodobniej orfickimi. Z zapisków znajdujących się na papirusie wynika, że mágoi pełnili tam następujące funkcje rytualne: wypowiadali zaklęcia skierowane przeciw daimones, które stały się przeszkodą; składali ofiary; wylewali na ofiarę libację z wody i mleka. Rytuał

${ }^{26} C f$. Faraone 1991: 19: „Whether the prayer is benevolent or malevolent is immaterial to the pious belief that the gods addressed can and will do what they are asked provided they are approached in a ritually correct manner”. $C f$. Lévi-Strauss 2000: 150: „[...] skuteczność magii, wymaga wiary w magię".

${ }^{27} C f$. Platon, Uczta, 188b-c: „Toż i ofiary wszelkiego rodzaju i to wszystko, co wchodzi w zakres sztuki wieszczbiarskiej - to przecież wszystko są objawy wzajemnego obcowania bogów i ludzi - to też nic innego, jak tylko pielęgnowanie i leczenie Erosa”, przeł. W. Witwicki (2006).

${ }^{28}$ Cf. Bremmer 2004: 569-574.

${ }^{29}$ Cf. Bremmer 1999: 1-12.

${ }^{30} C f$. Collins 2008: 54. Oprócz terminu mageia funkcjonował w języku greckim termin „goeteia” (goecja). „Magia” i „goecja” jako odrębne terminy pojawiły się w V w. p.n.e. Burkert przypuszcza, że goeta był kimś w rodzaju „szamana”, który zajmował się leczeniem.

31 Cyt. za: Biernat 2013: 32. 
ofiarniczy, jaki został opisany na papirusie w niczym nie odbiega od rytuałów, jakie spotykamy w religii Greków ${ }^{32}$. Herodot w Dziejach, wspominając z kolei o magach perskich, przekazuje, że zajmowali się oni składaniem ofiar, zwłaszcza przebłagalnych, recytowaniem teogonii podczas składania ofiar oraz interpretacją snów ${ }^{33}$. Według Ksenofonta magowie składali bogom ofiary i o świcie śpiewali hymny ${ }^{34}$. Wiele źródeł greckich i rzymskich przekazuje, że $\mu \alpha \gamma \varepsilon i ́ \alpha$ była pojmowana jako nieodłączna część służby dla bogów $(\theta \varepsilon \rho \alpha \pi \varepsilon i ́ \alpha \theta \varepsilon \tilde{\omega} v)^{35}$.

Arystoteles utrzymuje, że Magowie nie praktykowali goecji, czyli czarnej ma-

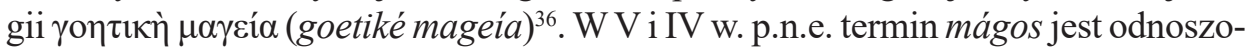
ny do różnego rodzaju specjalistów religijnych, którzy cieszyli się mniejszym lub

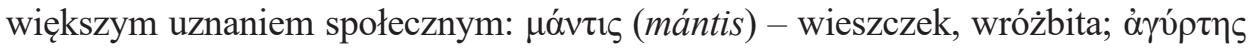
(agýrtes) - wędrowny kapłan, włóczęga utrzymujący się ze sprzedaży usług re-

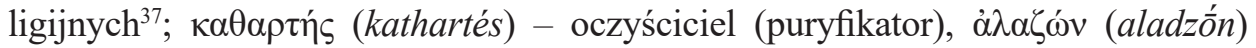

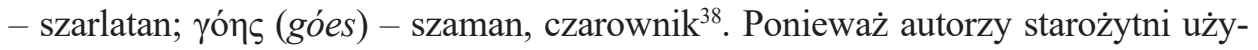
wali tych nazw w sposób wymienny, nie sposób jednoznacznie stwierdzić, czy dany specjalista religijny był kapłanem, szamanem czy też wieszczkiem. O ile w epoce archaicznej specjalista od sacrum nosił najczęściej miano mántis, o tyle w źródłach późniejszych nawet w stosunku do znanych i cenionych wieszczków pojawiają się jeszcze inne określenia: mágos, agýrtes, aladzón, góes, kathartés, iatrós.

Od niepamiętnych czasów największym prestiżem społecznym cieszyli się wróżbici. Ich praktyki magiczno-religijne związane ze „sztuką wieszczenia”

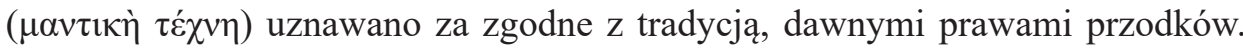
Jak wierzono, wieszczenie było powiązane z boską mocą, a wróżbita uchodził

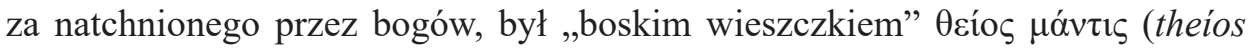
mántis $)^{39}$. Wróżbici byli postaciami charyzmatycznymi, niejednokrotnie pochodzili ze sławnych rodów, w których umiejętności mantyczne przekazywano z pokolenia na pokolenie. Ich prestiż był uzależniony od sprawdzalności przepowiedni; jeśli się potwierdzały, zdobywali nie tylko sławę, ale i bogactwo ${ }^{40}$. Sztuką wieszczenia pojmowaną nie tylko jako „sztuka rzemiosła”, ale i wiedza (mantiké téchne), (mantiké epistéme) zajmowali się kapłani i kapłanki obdarzeni

32 Cf. Trzcionkowski 2013: 339-342.

${ }^{33}$ I, 107-108; I, 120; I, 128; I, 132.

${ }^{34}$ Cf. Ksenofont, Wychowanie Cyrusa, VIII, 1.23.

${ }^{35} C f$. De Jong 1977: 213 oraz przyp. 29.

${ }^{36}$ Arystoteles, fr. 31.

${ }^{37} \mathrm{O}$ znaczeniu słowa agýrtes cf. Trzcionkowski 2013: 334-337.

${ }^{38}$ Cf. O świętej chorobie, I, 1-13, przeł. Wesoły 2008.

39 Platon, Uczta, XIII, 188, b.: „Wróżbiarstwo właśnie wytwarza przyjazny związek między bogami i ludźmi dzięki temu, że zna te poruszenia serca ludzkiego, które prowadzą do czynów sprawiedliwych i zbożnych", przeł. W. Witwicki 2006.

40 Cyt. za: Trzcionkowski 2005: 162-163: „Termin mantis oznacza zawodowego wieszczka, który ma specjalne zdolności do postawienia diagnozy transcendentnej w czasie kryzysu lub potrafi wskazać najlepszy sposób na skuteczne nawiązanie kontaktu z istotami nadprzyrodzonymi”. 
wyjątkowymi zdolnościami do komunikowania się z bóstwem, najczęściej w formie ekstatycznej chresmologowie, którzy wieścili w sposób spontaniczny, bez posługiwania się jakimikolwiek środkami. I jedni, i drudzy uprawiali swą mantiké téchne głównie w wyroczniach ${ }^{41}$, a ich sposób wieszczenia, za świadectwem Cycerona ${ }^{42}$, przywykliśmy nazywać wieszczeniem naturalnym. Jednym z najbardziej popularnych sposobów wieszczenia naturalnego, i w wyroczniach, i poza nimi, była oneiromantyka, czyli wróżenie na podstawie snów ${ }^{43}$. Istnieli także kapłani i wieszczowie zajmujący się wróżbiarstwem sztucznym, którzy wieszczyli ze znaków płanów, jak i wieszczków sprowadzała się do odczytywania tych pochodzących od bogów wiadomości ${ }^{44}$. Te znaki oraz sygnały występowały w różnej postaci i w różnych formach, ważne jednak było, aby konkretny znak miał, o ile było to tylko możliwe, obiektywny charakter ${ }^{45}$. Hieroskopia (odczytywanie znaków wróżebnych z wnętrzności składanych w ofierze zwierząt) należała do najważniejszego rodzaju wróżbiarstwa, bez niej nie podejmowano żadnych poważniejszych decyzji w sprawach polis, jak również w sprawach prywatnych, jeśli tylko osobę prywatną było stać na złożenie zwierzęcia w ofierze i zasięgnięcie porady wróżbity czy kapłana. „O ile przy każdej zwierzęcej ofierze, nawet nie połączonej z wróżeniem, obecność wieszczka była przynajmniej pożądana, chociażby tylko do dokonywania libacji, modlitw i innych obrządków rytualnych, o tyle przy wojsku w czasie wojny była bezwzględnie nieodzowna, i to do tego stopnia, że nie wystarczał byle jaki i nawet przeciętny wieszczek, lecz zabiegano o jak najlepszego, sprowadzając go nawet z zagranicy i nie skąpiąc ani zapłaty, ani nagród”46. Zaniechanie tej wróżby byłoby uznane za poważne lekceważenie nie tylko ta $\mathrm{pa}$ tria, ale także woli bogów. Gdy podejmowano decyzje o kluczowym znaczeniu dla wyniku zamierzonych czy prowadzonych działań wojskowych, a pierwsza ofiara i badanie wypadły niepomyślnie, powtarzano ją nawet parokrotnie dotąd, aż bogowie nie dali odpowiedniego, pomyślnego znaku. Wróżbiarstwo było powszechnie praktykowane podczas ceremonii publicznych, uznawano je za ważny element religii polis. Wieszczkowie towarzyszyli także władcom i wodzom jako ich doradcy. Obecność wróżbity była niezbędna przy zakładaniu kolonii. Do jego kompetencji należało złożenie ofiary, interpretacja znaków i wskazanie miejsca, które miało się stać centrum nowego miasta. Wróżbici oczyszczali również od

${ }^{41}$ Cf. Parker 1985: 298-326.

${ }^{42} C f$. Cyceron, $O$ wróżbiarstwie, I, 11-12.

${ }^{43}$ Cf. Homer, Odyseja, IV, 795-841; Iliada, II, 1-75; Herodot, Dzieje, I, 55, 2; I, 91, 5; Eurypides, Medea, 665-681.

${ }^{44} C f$. Cyceron, $O$ wróżbiarstwie, passim, przeł. W. Kornatowski (Kornatowski 1960); Oświecimski 1989: passim; Halliday 1913: passim; Burkert 2005: 1-51; 1: ,[... [ the human observation of perceived divine signs and the response to these"; Beerden 2013: passim; Johnston 2005: 2-27.

${ }^{45}$ Beerden 2013: 21: ,[...] the sign had to be objective”.

${ }^{46}$ Cyt. za: Oświecimski 1989: 39-40. 
zmazy, mieli więc też kompetencje puryfikacyjne (katartyczne). Źródła pisane

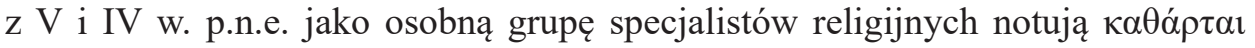
(kathártai); większość z nich najprawdopodobniej była wróżbitami, którzy wśród wielu umiejętności posiadali i tę, która umożliwiała oczyszczanie od zmazy (miasma). Grecy rozróżniali zmazę naturalną od moralno-religijnej. Zmazę naturalną powodowały: śmierć, narodziny, stosunek płciowy. Zmazę moralną wywoływały czyny bezbożne, była to zmaza „zawiniona”, sprowadzał ją gniew bogów, a jego skutkiem mogły być choroby, epidemie lub nawet zagłada całych miast. Wieszczkowie-puryfikatorzy oczyszczali ludzi od zmazy przy pomocy ofiar i inkantacji. W przypadku oczyszczeń ponownie możemy mówić o przenikaniu się dwóch sfer: religii i medycyny. To do wędrownych wieszczków zwracano się o pomoc, gdy szukano środków zaradczych na powstrzymanie zarazy czy epidemii. W większości przypadków praktyki religijne wieszczków były społecznie aprobowane, miały na celu zarówno dobro jednostki, jak i grupy społecznej ${ }^{47}$. Poszczególne poleis wielu z nich honorowały obywatelstwem ${ }^{48}$, dla wielu wzniesiono posągi mieszczące się w centrach religijnych.

Homer w Iliadzie wspomina o wieszczku Kalchasie, „spośród wróżbitów był najprzedniejszy”, który „wiedział wszystko, co było, co jest i co kiedyś się stanie"49. W epoce archaicznej działał słynny wróżbita Melampus, który oczyścił córki króla Projtosa od zmazy. Za swoje usługi miał otrzymać połowę królestwa ${ }^{50}$. Homer nazywa go wieszczkiem (mántis) ${ }^{51}$. Źródła późniejsze niż relacja Homera określają Melampusa nie tylko jako wieszczka, ale także jako człowieka, który dokonywał oczyszczeń (kathartés), maga (mágos), czarownika (góes), wędrownego kapłana zarabiającego na życie ,wszelkimi poradami z zakresu ducha i ciała" (agýrtes) ale także lekarza (iatrós). W VI w. p.n.e. działał wieszczek i poeta, Epimenides z Krety. Gdy w Atenach wymordowano zwolenników Kylona, którzy jako błagalnicy schronili się u ołtarzy, to właśnie jego poproszono o uwolnienie Aten od miasma, którą wywołało pogwałcenie prawa błagalników do nietykalności. Utrzymywano również, że Epimenides miał „nadzwyczajne zdolności przepowiadania przyszłości”, ${ }^{\prime}$.

Wieszczkiem, puryfikatorem, czarownikiem, wędrownym kapłanem zarabiającym na życie „,wszelkimi poradami z zakresu ducha i ciała”, nazywano zarówno

${ }^{47}$ Hubert i Mauss (1973: 1-208) w swym eseju o magii mocno akcentowali, że magia i obrzędy magiczne należą do tradycji, posiadają swoją skuteczność i są akceptowane przez całe społeczeństwo. Badacze ci przyjmowali jednak, że obrzędy magiczne nie były częścią zorganizowanego kultu, a miały jedynie charakter prywatny, nieregularny, tajemny.

${ }^{48} C f$. Biernat 2013: 33.

${ }^{49}$ Homer, Iliada, I, 69-70, przeł. K. Jeżewska (Jeżewska 1999).

${ }^{50}$ O Projtydach i Melampusie $c f$. Rybowska 2014: 97-235.

${ }^{51}$ Homer, Odyseja, XV, 223-245; 122.

${ }^{52}$ Diogenes Laertios, Żywoty i poglądy sławnych filozofów I, 10, 11, przeł. I. Krońska, K. Leśniak, W. Olszewski (Krońska et al. 1982). 
Orfeusza $^{53}$, jak i Pitagorasa. W podobny sposób wypowiadano się o wszystkich orfikach, „tych wokół Orfeusza”, jak ich nazywano. Byli tymi, którzy jako wędrowni kapłani wprowadzali w misteria, dokonując oczyszczeń i wtajemniczeń. „Wychodzili” ze swoimi naukami do tych wszystkich, którzy chcieli je naprawdę poznać. Byli tymi, którzy ze „świętości czynili sztukę”. Misteria orficko-bakchiczne „nie posiadały oparcia w żadnej świątyni. Jedyną ich ostoję stanowiła swoista literatura. [...] Odprawiano je częścią pod gołym niebem, częścią zaś w improwizowanych „kapliczkach Bakchosa” i domach mieszkalnych"54.

Za słynnego lekarza (iatrós), czarownika (góes) i cudotwórcę uznawano także Empedoklesa, filozofa i poetę z Akragas. Nie znamy dokładnych dat jego życia, najczęściej przyjmuje się, że jego szczytowy okres działalności przypada na połowę V. w. p.n.e. Doksografowie przekazują, że był twórcą wielu poematów, hymnów i tragedii, Arystoteles zaś, że był twórcą retoryki i nauczycielem sofisty Gorgiasza z Leontinoi, uznawanego za jednego z najwybitniejszych retorów. Z twórczości Empedoklesa zachowały się jedynie fragmenty poszczególnych dzieł i jego życiorys w dziele Diogenesa Laertiosa. Według tego ostatniego, Empedokles miał być uczniem Pitagorasa, a przyłapany na kradzieży wykładów mistrza, został pozbawiony prawa do uczestniczenia w nich. Część badaczy nie wyklucza, że Empedokles mógł słuchać wykładów otwartych, jakie były prowadzone we wspólnocie pitagorejczyków. W opinii Lengauera i Stebnickiej przekazy o działaniach i życiu Empedoklesa wykazują , wiele uderzających podobieństw z opowieściami o cudownych wydarzeniach z życia mędrca z Krotonu. Podobnie jak Pitagoras, tak i Empedokles w zachowanych o nim wzmiankach jest prezentowany jako cudotwórca, hierofant, prorok i szaman" ${ }^{\text {"55 }}$. Rzeczywiście, zachowane fragmenty twórczości Empedoklesa wskazują, że pełnił on wszystkie te role społeczne. Nasze wątpliwości budzi jedynie fakt, czy głoszone przez niego proroctwa miały swoje źródło tylko i wyłącznie w naukach pitagorejczyków, my nie wykluczalibyśmy także wpływu orfików ${ }^{56}$, ponieważ poglądy, jakie głosił poeta, odzwierciedlały nauki zarówno jednej, jak i drugiej wspólnoty. Widziano w poecie z Akragas cudotwórcę rozporządzającego wiedzą tajemną i umiejącego stosować tajemne praktyki. Jak przekazuje Diogenes Laertios, poskramiał on wiatry i wskrzeszał umarłych. Jako lekarz i wieszczek dysponujący nieprzeciętnymi zdolnościami, miał uratować mieszkańców Selinuntu od zarazy, jaka się tam szerzyła, a którą powodowały wyziewy pobliskiej rzeki; za radą Empedoklesa skierowano do niej płynące obok potoki i w ten sposób zmieszane wody oczyściły się. O podobnych umiejętnościach opowiada sam poeta w swoim poemacie $O$ naturze, informując jednego

${ }^{53}$ O Orfeuszu, legendarnym poecie i założycielu misteriów $c f$. Rybowska 2014: 161.

${ }^{54}$ Cyt. za: Krokiewicz 1947: 162. Trzcionkowski przyjmuje (2013: 310-312), że orfizm ,jako złożone zjawisko kulturowe rozpowszechniał się epidemicznie wieloma drogami”.

${ }^{55}$ Cyt. za: Lengauer, Stebnicka 1994: 14.

${ }^{56}$ Cf. Rybowska 2014: 175-176. 
ze swoich uczniów, Pauzaniasza, jaką wiedzą tajemną będzie dysponował, jeśli pozostanie wiernym uczniem swego mistrza:

Poznasz leki na choroby i na starość, gdyż tobie jednemu powierzę wszystkie te sekrety. Będziesz umiał uspokoić wściekłość wichrów gwałtownych, co po ziemi pędzą i swoim zgubnym wiewem niszczą zasiewy. I znowu, gdy zechcesz, potrafisz wzniecić wiatry uśpione, po czarnym deszczu susze ciepłą sprowadzisz, potrzebną ludziom, a w miejsce suszy gorącej znowu przywołasz deszcze, co z niebios spadają, aby dać pokarm drzewom, i z Hadesu na ziemię sprowadzisz zmarłego męża w całej jego sile ${ }^{57}$.

Z informacji, jakie przekazał nam o sobie filozof, możemy odtworzyć jego drogę życia. Rozpoczynał ją w świecie zwykłych śmiertelników, żyjąc zgodnie z prawami swych przodków. Składał w ofierze zwierzęta ofiarne i spożywał ich mięso. Po śmierci stał się daimonionem, przeszedł cały cykl wcieleń w różne istoty i doznał wszelkiego związanego z nimi cierpienia. Najprawdopodobniej, za sprawą wtajemniczeń w misteria bakchiczno-orfickie i życia zgodnego z życiem orfickim, przeszedł na wegetarianizm, a oczyszczenia i przejście różnych stopni wtajemniczeń przygotowały go do życia wiecznego. Stał się równy bogom.

O przyjaciele, co w wielkim mieście nad żółtym Akragasem mieszkacie, na jego akropoli, trosk pełni o dobre uczynki! Bądźcie pozdrowieni! Jako bóg nieśmiertelny, a nie jako człowiek śmiertelny przebywam teraz wśród was, otoczony czcią należną przez wszystkich, ozdabiany wstęgami i wieńcami zielonymi. Gdy tak przystrojony wchodzę do miast kwitnących, odbieram oznaki czci od mężów i kobiet! Idą za mną tysiące ludzi spragnionych wiedzy: jedni chcą ode mnie usłyszeć słowa wyroczni, inni, znękani chorobą, czekają na uzdrawiające zaklęcie ${ }^{58}$.

O tym, że wyżej przytoczony tekst nie jest jedynie fikcją literacką, upewniają nas zachowane zabytki archeologiczne, przede wszystkim złote tabliczki lamellae aurae zwane także „liściami Pamięci” czy też „darami Pamięci”. Pod tymi nazwami skrywa się cała seria tabliczek - w postaci złotych blaszek o bardzo małych rozmiarach (o szerokości od 4,2 do 8,1 cm i wysokości od 0,7 do 3,6 cm), które były wkładane zmarłym mystom do grobu, zarówno mężczyznom, jak i kobietom. Teksty ze złotych tabliczek wydają się wskazywać, że bakchoi mieli ściśle określoną drogę wtajemniczenia, co więcej, postępy owego wtajemniczania miały być ostatecznie weryfikowane w Hadesie przez strażników ,jeziora Mnemosyne”, jak i samą świętą i czystą królową świata podziemnego - Persefonę, którą mystoi pokornie błagali o „posłanie do siedzib błogosławionych”. „Liście Pamięci” nie odkrywają przed nami istoty i rytuałów wtajemniczenia, przez jakie musieli czy

${ }^{57} C f$. Diogenes Laertios, Żywoty i pogladdy sławnych filozofów, VIII, 59; 60, przeł. I. Krońska, K. Leśniak, W. Olszewski (Krońska et al. 1982). Cf. także Hippokrates, O świętej chorobie, I, 8-9: „Twierdzą, że potrafią ściągnąć księżyc, zaćmić słońce, wywołać sztorm i go uspokoić, sprowadzić deszcz albo suszę i uczynić ziemię lub morze jałowym, czy to z rytuałów czy z jakiejś innej formy wiedzy lub praktyki”. Cyt. za: Biernat 2017: 184.

${ }^{58}$ Empedokles, fr. 112; cyt. za: Jastrzębski 2014: 5. 
też powinni byli przejść bakchoi. Jednakże treść tych tabliczek wydaje się wskazywać, że ich status post mortem ulegał całkowitej zmianie - ze zwykłych śmiertelników stawali się bogami i zamieszkiwali w Elisium ${ }^{59}$. Najprawdopodobniej Empedokles, utrzymując, że stał się bogiem czy też równy bogu, informuje nas o tym, że jako oczyszczony i znający hasło w Hadesie będzie cieszył się życiem wiecznym, w przeciwieństwie do tych, którzy nie przeszli wtajemniczeń.

Poemat Empedoklesa spisany heksametrem i zatytułowany Katharmoi (Oczyszczenia), w swojej pełnej wersji liczył dwa tysiące wierszy zamieszczonych w dwóch księgach. Zachowały się z niego jedynie nieliczne fragmenty, a właściwie strzępy. $\mathrm{Na}$ ich podstawie niepodobna stwierdzić, czy zawierał on jakiekolwiek wskazówki związane z religijnym obrzędem oczyszczania. Starożytni utrzymywali, że śmierć poety z Akargas nie była śmiercią zwykłego śmiertelnika. Filozof najpierw sprosił do siebie swoich przyjaciół na przyjęcie, a gdy ci się rozeszli, aby sympozjon odespać, on po prostu zniknął. O północy ktoś ,usłyszał potężny głos wołający Empedoklesa”, po czym widziano „światło na niebie i blask pochodni”. Jego ukochany uczeń Pauzaniasz uznał, że uczestnicy sympozjonu powinni się wspólnie pomodlić i „złożyć ofiarę Empedoklesowi jako nowemu bogu”"00.

Postaci Kalchasa, Melampusa, Epimenidesa czy też Empedoklesa, o których wzmiankowaliśmy lub które pokrótce przedstawiliśmy, to jedynie wybrane przykłady ludzi, których Grecy uznawali przede wszystkim za wieszczków, a w drugiej kolejności za lekarzy, magów, czarowników. Wielu z nich było postaciami wybitnymi, a wpisane w ich życiorysy cuda: wskrzeszania zmarłych, zatrzymywanie wiatrów, sprowadzanie deszczu, ściąganie księżyca, to nic innego jak zachowania rytualne, obecne tak w religii, jak i magii starożytnych Hellenów. Od wybitnego wieszczka oczekiwano nie tylko wiedzy o tym, co było, jest i będzie, ale także różnorakich remediów, w tym działań magiczno-rytualnych, które umożliwiały zażegnanie chorób i epidemii ${ }^{61}$.

${ }^{99} C f$. Tekst z tabliczki z Pelinny (OF 485); tekst z tabliczki z Hipponion (OF 474 B) 635. Szerzej na temat tabliczek i misteriów orficko-bakchicznych $c f$. Rybowska 2014: 147-194.

${ }^{60} C f$. Diogenes Laertios, VIII, 68, przeł. I. Krońska, K. Leśniak, W. Olszewski (Krońska et al. 1982).

${ }^{61}$ Chociaż w naszych rozważaniach skupiamy się na religii i magii ceremonialnej, to jednak należy zasygnalizować i to, że dla Greków słowo mageía miało związek zarówno z poezją, jak i wymową. Uznawano, że zarówno magia, jak i poezja pochodziły od bogów. Grecy w pełni zdawali sobie sprawę z faktu, że pieśń czy też mowa, podobnie jak działania magów, czarowników, mogła oczyszczać, ale i zwodzić, oszukiwać. Szczególny nacisk na związek słowa pisanego i mówionego z pobożnością, opieką bogów nad słowem, kładli przedstawiciele Drugiej Sofistyki. Ta ostatnia była nurtem literackim i społecznym, który rozwinął się w świecie greckim epoki Cesarstwa Rzymskiego, w okresie od I do III w. n.e. Już w starożytności za męża bogobojnego uznawano retora i przedstawiciela Drugiej Sofistyki, Eliusza Arystydesa. Mówca ten spędził wiele lat na kuracjach zalecanych mu przez boga Asklepiosa. Najpierw przebywał na leczeniu w świątyniach w Rzymie, następnie w Asklepiejonie smyrneńskim. W latach 145-147 n.e. na stałe przebywał w świątyni Asklepiosa w Pergamonie. Przez kolejnych siedemnaście lat kierował się w swym życiu przede wszystkim zaleceniami przekazanymi mu przez boga Asklepiosa, nakazami przekazywanymi mu podczas snu. Również podążając za radą 
Część badaczy przyjmuje ${ }^{62}$, że ich praktyki nie miały już nic wspólnego z religią, ale dotyczyły misteriów lub były jedynie „czystą magią”, w dodatku „czarną magią". Byli to ludzie, nierzadko obcego pochodzenia, nieakceptowani społecznie. Podobnie jak Biernat przyjmujemy, że specjaliści ci nie byli ,ani przybyszami ze zmitologizowanego wschodu, ani nowinkarzami, którzy wywracali tradycyjną religię do góry nogami, lecz wyrastali z greckiej tradycji, która nie znała naszego rozdziału między religią, medycyną a magią"63.

Zachowane w literaturze opinie na temat „kapłanów-włóczęgów”, utrzymujących się ze sprzedaży usług religijnych, były podzielone ${ }^{64}$. Negatywne opinie o nich odnajdziemy u tragików i retorów. Gdy przepowiednia nie podobała się klientowi lub nie była po jego myśli, na miano „maga” zasługiwali nawet wybitni wieszczkowie. Najwięcej informacji o ich działalności zawdzięczamy Platonowi, ale i on miał do nich zdecydowanie ambiwalentny stosunek. Wypowiedź Adejmantosa z Państwa Platona to ważne źródło do poznania metod działania wędrownych specjalistów i zakresu ich usług religijnych w IV w. p.n.e.:

Do tego jeszcze wędrowni kapłani (agyrtai) i wieszczkowie (manteis) pukają do bogatych domów i przekonują, że za sprawą ofiar i zaklęć pozyskali od bogów moc, by uzdrawiać podczas przyjemnych uroczystości, jeśli ktoś albo czyjś przodek popełnił występek. Co więcej, jeżeli ktoś chciałby zaszkodzić swojemu wrogowi, za małą dopłatą skrzywdzą

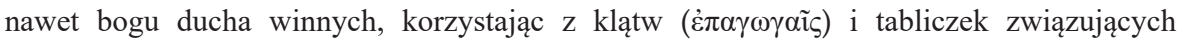

swego bóstwa Arystydes zaczął spisywać swe sny. Świadectwem tych zapisków są tak zwane Hieroi Logoi oraz tzw. „Mowy wieszczące”. Jak wynika to z uwag poczynionych w wyżej wymienionych utworach Arystydes uznawał się za sługę i ,boskiego thumacza” boga Asklepiosa. Bóg nie tylko miał pomagać retorowi w odzyskaniu zdrowia w trudnej karierze mówcy i twórcy literatury, ale to jego łasce miał zawdzięczać także przedłużenie swego życia co najmniej o kilka lat. Flawiuszowi Filostratowi również przedstawicielowi Drugiej Sofistyki, zawdzięczamy informacje o kolejnych sofistach, którzy poszukiwali opieki tego samego bóstwa. W Żywotach sofistów pisarz utrzymuje, że mówca Antioch z Aigaj w Cylicji, miał spędzić wiele nocy w świątyni Asklepiosa, oczekując na sny i prowadząc rozmowy z czuwającymi. Z kolei w Żywocie Apolloniosa z Tyany pisarz przekazuje, że Apollonios w młodości pełnił służbę uzdrowiciela w świątyni Asklepiosa w Ajgaj. W Asklepiejonie miał też stać się jednym z pitagorejczyków, ściśle przestrzegającym wszystkich ustanowionych we wspólnocie reguł. Wedle Filostrata, Apollonios był człowiekiem nadzwyczajnym i boskim. Po opuszczeniu Asklepiejonu wiele podróżował, nauczał i miał własnych uczniów, którzy towarzyszyli mu w drodze. Dokonywał też wielu cudów. Apolloniosa z Tyany Filostrat przedstawia jako jednego z sofistów, chociaż w rzeczywistości nim nie był. Oprócz dzieła Filostrata o Apolloniosie z Tyany wzmiankują również inne źródła, które nie przedstawiają go już w tak korzystnym świetle. Jak się przyjmuje Apollonios żył na przełomie I i II w. n.e., nie wspominają o nim żadne współczesne mu źródła. Po raz pierwszy wspomina o nim Lukian, w utworze Aleksander albo fatszywy prorok. Według satyryka Apollonios był wróżbitą, manipulatorem i oszustem. Jedyną wiedzą jaką dysponował była znajomość leków przeciw rożnym chorobom. Należy jednak podkreślić, że Lukian uznawał wróżbiarstwo i przepowiednie za umysłową truciznę. W III i IV w. n.e. pisarze porównywali Apolloniosa z Chrystusem (Porfyriusz, Hierokles).

${ }^{62}$ Cf. Wypustek 2001: 43.

${ }^{63}$ Cyt. za: Biernat 2013: 35.

${ }^{64}$ Cf. Sieradzan 2011: 92-94. 


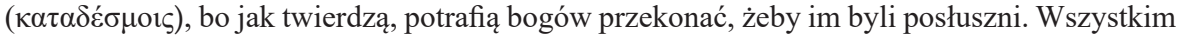
tym słowom na świadków przywołują poetów, którzy pobłażliwie pisali o niegodziwości, że „zło można łatwo brać nawet na kopy: droga doń prosta i blisko położona. Za to przed cnotą bogowie trud położyli”, a droga do niej długa, stroma i uciążliwa. Inni zaś zaświadczają się Homerem, że ludzie mogą zwodzić bogów, ponieważ i on powiedział, że i „bogów można uprosić, więc ludzie błagając odwracają ich gniew ofiarami i grzecznymi modlitwami, libacją i tłustym dymem, jeżeli ktoś popełni występek lub uchybienie". I mają ze sobą wrzawę ksiąg Muzajosa i Orfeusza, ,potomków Seleny i Muz, jak twierdzą, podług których składają żertwę, przekonując nie tylko ludzi prywatnych, ale i całe miasta, że istnieją uwolnienia i oczyszczenia z przewin za pomocą ofiar i przyjemnych zabaw i że jedne są dla żywych, a inne dla umarłych - te drugie nazywają teletai i mówią, że uwalniają nas od złych rzeczy po drugiej stronie, a kto by tych ofiar nie złożył, tego czeka coś strasznego ${ }^{65}$.

To, co Platon nazywa proszeniem bogów i ,przekupywaniem” ich za pomocą modlitw, libacji i tłustego dymu, to nic innego jak najważniejsze sposoby nawiązywania kontaktów $\mathrm{z}$ bogami. W dziesiątkach greckich poleis podczas wielu oficjalnych ceremonii religijnych Grecy nie tylko oddawali cześć bogom, ale pozyskiwali w ten właśnie sposób ich przychylność, oczekując od bogów odwzajemnienia cháris (wdzięczności) za otrzymane dary. Ofiary te były składane przez kapłanów i wróżbitów, a ich rola polegała na pilnowaniu, aby zostały one złożone zgodnie z ta patria. Negatywny stosunek Platona do tradycyjnej therapeía theōn wpływał również na jego opinię o różnego rodzaju specjalistach religijnych. Uwaga filozofa o kapłanach, którzy utrzymywali, że potrafią „,uzdrawiać, leczyć od win przodków oraz innych przewin zarówno za życia, jak i po śmierci”, jest czymś, co wykraczało poza obręb religii polis. Informacje te odnoszą się do wędrownych kapłanów wtajemniczających w misteria orficko-bakchiczne. W tradycyjnych wierzeniach Greków bogowie byli przede wszystkim mocami czuwającymi nad sprawiedliwością i przestrzeganiem prawa, ale przedmiotem tej sprawiedliwości nie były jednostki, lecz całe rody, a wina, podobnie jak zasługa, była dziedziczna. Za bezbożne czyny rodziców karę ponosiły dzieci, chociaż same nie były winne naruszenia niepisanych praw ustanowionych przez bogów, co więcej, karę tę mogły dziedziczyć także kolejne pokolenia. Kara ta mogła doprowadzić nie tylko do całkowitego zaniku rodu, ale także zniszczenia całej polis. Kapłani misteriów orficko-bakchicznych zapewniali, że wtajemniczeni w te misteria zostaną wyzwoleni od odpowiedzialności za winy przodków, a po śmieci spotka ich lepszy los w Hadesie niż ten, jaki czekał wszystkich niewtajemniczonych. Misteria były częścią religii Greków, tyle tylko, że religią niezwiązaną z polis.

Całkowicie odmienny sens ma natomiast relacja Platona o agýrtai i mánteis, którzy utrzymywali, iż potrafią sprawić, aby bogowie byli im posłuszni. W tradycyjnych wierzeniach Greków człowiek próbował zyskać łaskę bogów, a posłuszeństwa domagali się od ludzi nieśmiertelni. W tym zakresie oddalamy się od

${ }^{65}$ Platon, Państwo, 364c-365a, przeł. Biernat (Biernat 2017: 136-137). 
tradycyjnych wierzeń i wkraczamy na teren antycznej magii. Podobnie rzecz wygląda, jeśli chodzi o umiejętności zaszkodzenia dowolnie wybranej osobie i spisywania „tabliczek związujących”. I w tym przypadku ,umiejętności” wędrownych kapłanów balansowały na granicy magii i religii, jak powiedzieliby znawcy antyku, albo, jak określają to współcześni etnolodzy - „czarownictwa”. Ten ostatni termin jest definiowany jako ,proceder uprawiania czarów, a więc czynności zmierzających do sprowadzenia zła na jednostki i grupy społeczne" ${ }^{96}$. Sporządzeniu tabliczki, uruchomieniu jej wiążących mocy, towarzyszyły elementy rytuału z pogranicza religii i magii. Magowie potrafili niekiedy uciekać się do przestępstw przy sporządzaniu zaklęć. Aby pozyskać odpowiednie proszki, pharmaka, uciekali się niekiedy do zdrapywania posągów, stel, elementów świątyń. Kiedy już wyryto zaklęcie, wzmacniano je odpowiednimi rytuałami, inkantacjami, ofiarami. Ceremonie odbywały się przed świtem lub nocą. ,Tabliczki związujące” (de-

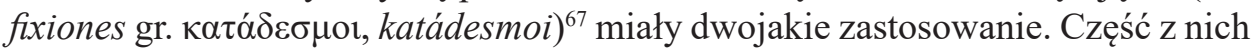
była spisywana w formie skargi na doznaną krzywdę z prośbą do bóstw o ukaranie niegodziwego lub niesprawiedliwego człowieka. Pozostałe służyły różnym indywidualnym celom, które wiązały się z wyrządzeniem krzywdy innemu człowiekowi ${ }^{68}$. Świadectwa pochodzące $z$ literatury magicznej prezentują olbrzymią rozmaitość zaklęć, jakie magowie byli w stanie zaoferować potencjalnym klientom. Na każdą okoliczność było jakieś zaklęcie. Słowa zaklęć wyskrobywano na różnego rodzaju przedmiotach lub zapisywano na papirusach. Utrwalone w formie spisanej były rolowane i często przebijane, a następnie umieszczano je w sekretnych miejscach. Zakopywano je w ziemi, wkładano do grobów, zanoszono na rozstaje dróg, wrzucano do wody, umieszczano w świątyniach bóstw związanych ze światem podziemnym ${ }^{69}$. Adresatami tych zapisków były najczęściej bóstwa świata podziemnego i boscy patroni magii: Hermes, Kora/Persefona, Hekate, Hades/Pluton, Ge i Demeter ${ }^{70}$. Inskrypcje z zaklęciami odnajdywano wszędzie tam,

${ }^{66}$ Cyt. za: Zimoń 2011: 82.

${ }^{67}$ O wydaniach tabliczek z przyjmowanymi skrótami $c f$. Audollent 1967; Gager 1992; Faraone, Obbink 1991; Wypustek 2011.

${ }^{68} \mathrm{~W}$ dobie współczesnej defixiones podzielono na kilka grup, uzależniając ich przynależność od okazji, z jakiej zostały spisane. Pierwszy podział defixiones zawdzięczamy Audolentowi, który dokonał go na podstawie 300 odkrytych zaklęć. Wyodrębnił wśród katadesmoi następujące grupy: 1) defixiones iudicariae - związane z procesami sądowymi. Zaklęcia tego typu były kierowane wobec strony przeciwnej w toczących się procesach; 2) defixiones in fures - zaklęcia w sprawie kradzieży i oszustwa. Ta grupa zaklęć występuje niekiedy jako część defixiones iudicariae; 3) defixiones amatoriae - dotyczyły spraw miłosnych i erotycznych; 4) defixiones ludicaraelagonosticae - były kierowane przeciwko rywalom w sporcie, we wszelakich agonach, z teatralnymi włącznie; 5) defixiones związane z działalnością zawodową („,biznesową”), których celem było doprowadzenie do wyeliminowania konkurencji, ,popsucie interesu”. Podaję za: Wypustek 2001: rozdz. Defixiones, czyli zaklęcia na tabliczkach.

${ }^{69} C f$. Dufault 2017: 31-49.

${ }^{70} C f$. Bremmer 2010: 13-35. 
gdzie obecni byli Grecy, od Hiszpanii po Bliski Wschód i od północnych wybrzeży Morza Czarnego po Egipt ${ }^{71}$.

Jak przyjmuje to wielu badaczy, pierwotnie defixiones funkcjonowały jedynie $\mathrm{w}$ formie oralnej i były wypowiadane podczas rytuału magicznego. Zaklęcie spisane w najprostszej formie zawierało jedynie imię boga i prośbę o wyrządzenie krzywdy, o „związanie NN”, a w rozbudowanej formie przybierało postać modlitwy. Zdecydowana większość defixiones zawiera jedynie zapiski w postaci krótkich listów, „e-maili pisanych do bogów” - jak żartobliwie określa je Versnel ${ }^{72}$. Treścią tych listów była skarga i domaganie się zadośćuczynienia od bogów, które czasami miało postać pokornej prośby, a innym razem wręcz stanowczego żądania. Preces, jakie odnajdujemy na katádesmoi, brzmią: ukarz! Ukarzcie! Najczęściej listy z prośbą o ukaranie kogoś, „o związanie” go były kierowane do boga Hermesa i bóstw związanych ze światem podziemnym:

DTA 103: Wysyłam ten list do Hermesa i Persefony, ponieważ kieruję to zaklęcie przeciwko

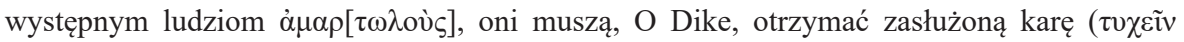

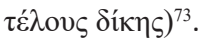

Krytykę różnego rodzaju wędrownych kapłanów, odnajdziemy także w traktacie medycznym $O$ świętej chorobie (De morbo sacro) pochodzącym ze zbioru Corpus Hippocraticum. Autor tego dzieła zarzuca specjalistom religijnym, że traktują epilepsję jako świętą chorobę, i jako taką leczą za pomocą oczyszczeń:

Mnie osobiście wydaje się, że pierwsi, którzy tej chorobie nadali znamię świętości, to ludzie, jacy istnieją i dziś: magowie i oczyściciele, żebrzący kapłani i szarlatani - oni wszak podają się za wielkich czcicieli bóstw i osoby bardziej się na tym znające. [...] Posługują się oczyszczeniami i zaklęciami, a przy tym popełniają rzecz - jak mi się wydaje - najbardziej świętokradczą i bezbożną. Mianowicie oczyszczają dotkniętych chorobą przy pomocy krwi i innych tego rodzaju rzeczy, jak gdyby byli oni dotknięci zmazą. A są nią dotknięci przecież ci, którzy popełnili zbrodnię [dosł. ciąży nad nimi duch zemsty], padli ofiarą czarów, albo popełnili jakiś bezbożny czyn. [A z chorymi na epilepsję] należałoby inaczej postępować, oni powinni: złożyć ofiarę, modlić się i przybywać do miejsc świętych, aby błagać bogów. Natomiast oni niczego takiego nie robią, tylko oczyszczają. A co do przedmiotów służących do oczyszczeń to jedne ukrywają w ziemi, inne wrzucają do morza, jeszcze inne wnoszą na góry, gdzie nikt ich nie pochwyci i nie nadepnie na nie. A rzeczy te należałoby raczej zanieść do świątyń i złożyć bogu w ofierze, jeśli to istotnie bóg jest przyczyną tej choroby ${ }^{74}$.

${ }^{71}$ Dotychczas odkryto ponad 1600 katádesmoi datowanych między VI w. p.n.e. a VIII w. n.e. Najstarsze z nich pochodzą z Sycylii i z Olbii. Największy ich zbiór pochodzi z Aten, gdzie były one odnajdywane na cmentarzu Keramejkos i w porcie w Pireusie; zabytki te są datowane na V w. p.n.e.

${ }^{72} C f$. Versnel 2002: 60.

73 Przeł. J. Rybowska.

${ }^{74}$ Hippokrates, O świętej chorobie, I, 4; I, 12, przeł. M. Wesoły z uzupełnieniami J. Rybowskiej (Wesoły 2008). 
Opisane przez autora traktatu poczynania magów z chorymi na epilepsję były zgodne z wierzeniami i praktykami religijnymi starożytnych Greków. W tego typu przypadkach „oczyszczenie” następowało przy pomocy krwi pozyskanej od zwierzęcia. Jak przypuszcza Parker, krew była najprawdopodobniej fizycznym znakiem zanieczyszczenia, które miało zostać usunięte ${ }^{75}$. Po jego zakończeniu pozbywano się rzeczy, z których korzystano podczas puryfikacji. Biernat słusznie podkreśla, że „przeprowadzona przez autora traktatu krytyka [...] sprowadza się do wykazania sprzeczności w rozumowaniu specjalistów religijnych. [...] Uwagi te mają charakter teologiczny, a nie medyczny"76. Argumentację przedstawioną w cytowanym dziele można sprowadzić do następujących stwierdzeń: jeśli choroba pochodziła od bóstwa, to chory powinien dziękować za nią bogu, a nie oczyszczać się od zmazy. Ponadto bóstwo nie może być dla człowieka źródłem zmazy.

Według Collinsa, najbliższe pierwotnemu znaczeniu słowa magia i mag by-

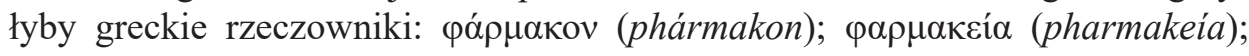

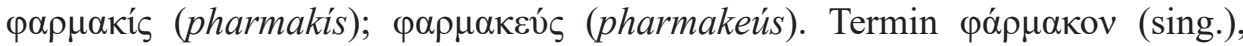
фа́ $\mu \alpha \kappa \alpha$ (plur.) miał szerokie i ambiwalentne znaczenie - lek, lekarstwo, trucizna, trujące ziele, napój zaczarowany, napój miłosny, czary, uroki, gusła. Stąd фарнакєí $\alpha$ - zastosowanie lekarstw, stosowanie narkotyków, czarów, truciciel-

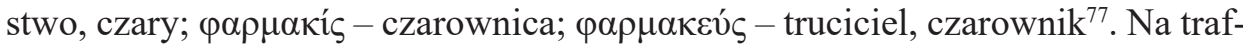
ność spostrzeżeń Collinsa wydaje się wskazywać fakt, że w inny sposób oceniano działalność społeczną tych, którzy preparowali phármaka, a jeszcze inaczej oceniano wszystkich pozostałych specjalistów religijnych. W starożytnej Grecji nie notujemy oskarżeń z powodu trudnienia się magią czy jej uprawiania. Nie zna-

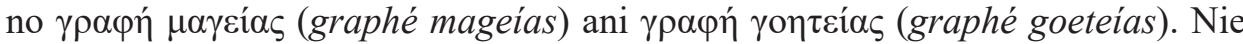
skazywano również za nekromancję ${ }^{78}$. Przewidywano natomiast ciężkie kary dla tych wszystkich, którzy preparowali trucizny i używali ich w stosunku do innych. W Atenach można było wystąpić z oskarżeniem o asebeia w stosunku do osoby, którą podejrzewano o trucicielstwo, posługiwanie się phármaka ${ }^{79}$. Jak wynika to $\mathrm{z}$ jednego z zachowanych leges sacrae, równie surowo jak w Atenach traktowano trucicieli na Teos:

Ktokolwiek sporządza substancje trujące (pharmaka), a następnie [używa ich] przeciw mieszkańcom Teos jako jednostkom bądź członkom wspólnoty, powinien umrzeć, zarówno on, jak i jego rodzina ${ }^{80}$.

${ }^{75}$ Cf. Parker 1996: 234

${ }^{76}$ Cyt. za: Biernat 2013: 30.

${ }^{77} C f$. Collins 2008: 28. Autor uznaje, że termin pharmakon funkcjonował w j. greckim znacznie wcześniej niż rzeczownik mageia.

${ }^{78}$ W starożytnej Grecji w przeciwieństwie do Rzymu nie karano za nekromancję. $C f$. Ogden 2001: passim; Bremmer 2016: 119-141.

${ }^{79} \mathrm{O}$ procesach Ninos i Theoris $c f$. Dickie 2003: 49-53.

${ }^{80}$ Cytuję i podaję za: Sieradzan 2011: 131. 
Kolejną, wskazywaną przez współczesnych badaczy różnicą, jaka miała oddzielać religię od magii, były różne formy rytuału, jakie towarzyszyły obu tym dziedzinom. Z magią miały być związane zaklęcia, klątwy, amulety, „pętanie” czy też „wiązanie”. Religia miała pozostawać wolna od tego typu praktyk. Tym, co przede wszystkim różniło magię od religii była forma modlitwy.

Zaklęcia, klątwy, złorzeczenia, wiązanie za pomocą przysiąg funkcjonowały zarówno w religii, jak i magii. Ośmielę się nawet stwierdzić, że były one nieodłączną częścią kultury starożytnych Greków. Powszechny był wśród Greków zwyczaj obrzucania się klątwami podczas składania przysiąg. Przysięga była aktem sakralnym, nad jej przestrzeganiem czuwali bogowie, którzy byli wzywani na świadków przysięgi. Klątwa była formą wezwania bóstwa do wyrażenia swego gniewu wobec tych, którzy złamaliby postanowienie przysięgi. Określała ona zakres tej zemsty. Eidinow słusznie podkreśla, że Grecy uciekali się do wróżbiarstwa, klątw, tabliczek związujących w sytuacji niepewności i podejmowania ryzyka ${ }^{81}$. Amulety odgrywały równie ważną rolę w greckiej medycynie, w kulcie bogów, jak i w magii. Te ostatnie miały dwojaki charakter apotropaiczny, a więc chroniący przed złem, ale jak wynika to z literatury magicznej, były również sporządzane w celu wyrządzenia zła innemu człowiekowi.

We współczesnych badaniach bardzo mocno się akcentuje, że religię określa zależność od bóstwa i podporządkowanie wyrażające się w języku prośby i błagania, natomiast magię cechuje stosunek wyrażający rozkaz czy też nakaz. W religii kapłan, zważając na normy religijne obowiązujące w danej kulturze, składa hołd

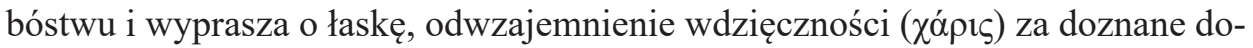
bra. Jego modlitwa była prośbą w imieniu całej wspólnoty. Mag natomiast żądał, manipulował i wymuszał na bóstwach to, czego pragnął on sam bądź jego klient.

Nie sposób zaprzeczyć, że istniała różnica pomiędzy modlitwą củxý (euché), która była ważną częścią $\theta \varepsilon \rho \alpha \pi \varepsilon i ́ \alpha ~ \theta \varepsilon \tilde{v} v$ i służyła celom łączącym wspólnotę, a modlitwą towarzyszącą sekretnym rytuałom, którą spisywano w celu osiągnięcia konkretnych, indywidualnych celów. Pomimo to powinniśmy wziąć pod uwagę także i ten fakt, że eỏxý była najczęściej pieśnią kultową, która towarzyszyła ważnym wydarzeniom religijnym. Tego rodzaju pieśni komponowali najwybitniejsi poeci. Pojmowano je zatem jako dar dla boga i wyraz okazywanej mu wdzięczności, jedną z najpiękniejszych form „handlu z bogami" ${ }^{2}$. Ale, jak możemy to wnosić chociażby z poematów Homera, zupełnie inną postać miały modlitwy Greków, którzy znajdowali się w trud-

${ }^{81}$ Eidinow 2007: 4, 13.

${ }^{82}$ W opinii Versnela, (1981: 56): „[...] w starożytności nic nie było za darmo: ani bogowie, ani ludzie nie byli skłonni do bezinteresownej życzliwości [...]. Element wymiany był fundamentalny w kontaktach z bóstwem [...]. Człowiek dał i bóg musiał odpowiedzieć innym darem i vice versa". Modlitwa, tak jak inne dary przeznaczane dla bogów, była „formą handlu z bogami”. W ocenie Parkera (1988: 120) Grecy nawet w sferze religijnej manipulowali bogami, aby nakłonić ich do bliższego kontaktu ze śmiertelnikami bądź użyczenia ludziom tego wszystkiego, czego bez opieki bogów nie byliby w stanie sami pozyskać. 
nej sytuacji lub prosili o wzięcie odwetu za wyrządzoną im krzywdę. Inną postać miały również modlitwy towarzyszące przysięgom; zawierały maleficium ${ }^{83}$, klątwę, służyły partykularnym interesom jednostki bądź wybranej grupie osób i tylko w niewielkim stopniu różniły się od modlitw zapisywanych na katádesmoi ${ }^{84}$.

Defixio in fures, odnalezione w pobliżu Arkesine na egejskiej wyspie Amorgos (I w. p.n.e - I/II w. n.e.), jest przykładem zaklęcia zbliżonego do modlitwy. Podobieństwo do euché jest widoczne w evocatio i w podniosłym stylu prośby, który był charakterystyczny dla modlitw; natomiast część środkową tego katadesmos wypełniają skarga pokrzywdzonego oraz nie tyle maleficium, ile maleficia - cała litania klątw wymierzonych przeciwko złoczyńcy. W preces bogini Demeter jest proszona o wymierzenie sprawiedliwości, ale spełnienie tej prośby oznaczało wyrządzenie zła drugiemu człowiekowi:

Pani Demeter, królowo, jako twój błagalnik, padam do twych stóp, twój niewolnik. Pani Demeter, o to co mnie spotkało. Opuszczony szukam schronienia w tobie: bądź łaskawa dla mnie i zapewnij mi me prawa. Spraw, że człowiek, który potraktował mnie w ten sposób, nie będzie miał zadowolenia ani spoczynku, ani w ruchu, ani w ciele, ani w duszy, że nie będzie obsługiwany ani przez niewolnika albo niewolnicę, ani przez dużego, ani przez małego. Jeśli podejmie się czegoś, niech nie będzie w stanie [tego] skończyć. Niech jego dom będzie dotknięty przekleństwem na zawsze. Niech [w jego domostwie] żadne dziecko nie kwili; niech nie zasiądzie nigdy do radosnej biesiady; niech żaden pies ani żaden kogut nie pieje, niech sieje, ale nie zbiera [...] niech ani ziemia ani morze nie przyniosą mu żadnego owocu; niech nie zazna błogosławionej radości; niech przepadnie wraz ze wszystkim, co do niego należy. Pani Demeter, błagam cię, bo ucierpiałem niesprawiedliwość: wysłuchaj mnie bogini, i wydaj sprawiedliwy wyrok. Tym, którzy to obmyślili, cieszącym się złośliwie i czyniącym krzywdy mnie i mojej żonie ${ }^{85}$.

Zaprezentowany materiał dowodzi, po pierwsze, że modlitwy funkcjonowały tak w religii, jak i magii. Po drugie, że forma „manipulowania bogami” czy też raczej „handlowania z bogami” była charakterystyczna nie tylko dla praktyk magicznych. Po trzecie, jest świadectwem wzajemnego przenikania się praktyk religijnych i magicznych na terenie różnych regionów.

Religia, tak jak i magia są $-\mathrm{z}$ definicji - przedmiotem wiary. Wiary $\mathrm{w}$ to, że bóstwo, do którego się zwracano, było w stanie przyjść człowiekowi z pomocą. Niektórzy badacze, podkreślający różnicę dzielącą religię od magii, akcentują, że w przypadku religii jej wyznawcy zwracali się do bogów/Boga czczonych oficjalnie w kultach państwowych czy też powszechnie akceptowanych przez jaką́ społeczność, natomiast w przypadku magii zwracano się „ku nadnaturalnej, ożywionej i tajemniczej stronie rzeczywistości”" ${ }^{\prime \prime}$.

${ }^{83} \mathrm{O}$ znaczeniu maleficium $c f$. Posacki 2009: 39.

${ }^{84}$ Cf. Homer, Iliada, III, 269-301.

${ }^{85}$ SGD 60. Cf. Homolle 901: 412-430; IG XII.72 (Wypustek 1997: 251).

${ }^{86} C f$. Wierciński 1994: 103: „magia to zbiór czynności obrzędowych skierowanych ku nadnaturalnej, ożywionej i tajemniczej stronie rzeczywistości, oraz zmierzających, poprzez instrumentalne oddziaływanie na nią, do wymuszenia zajścia pożądanej zmiany w otoczeniu". 
W starożytnej Helladzie pojmowano bogów jako wielkie nadnaturalne Moce, które mogły objawiać się człowiekowi w różnej postaci, oddawano im cześć zarówno w postaci fitomorficznej, zoomorficznej, jak i antropomorficznej. Wielu z tych bogów miało szerokie i bardzo różne kompetencje. Oddawano im cześć podczas oficjalnych świąt, zapisanych w kalendarzach kultowych, ale zwracano się również do tych samych bogów podczas obrzędów magicznych, które nie były częścią zorganizowanego kultu, a były obrzędami prywatnymi, sekretnymi, tajemnymi. Najczęściej były to bóstwa określane mianem bóstw liminalnych: Hekate, Hermes, Persefona, Demeter, Pluton/Hades.

Bóg Hermes, który według Greków narodził się w Arkadii, miał, jak można przypuszczać, o wiele starsze korzenie. Większość badaczy uznaje za rzecz niebudzącą sprzeciwu jego podobieństwa do wedyjskiego boga Pūsána ${ }^{87}$. Zgodnie z Rygwedą Pūsán czczony był przede wszystkim jako opiekun pasterzy i pasterstwa oraz bóstwo agrarne; pomagał w pomnażaniu zwierząt i odnajdywaniu zaginionych sztuk. Pūsán jako dobry bóg-pasterz czuwał także nad drogami i wędrowcami, prowadząc ich bezpiecznie do celu. $Z$ tą funkcją wiązała się również rola Pūsána jako boskiego drużby, który towarzyszył pannie młodej podczas podróży do domu męża. Był uznawany również za boskiego posłańca, który krążąc między ziemią a niebem, odprowadzał dusze zmarłych w zaświaty. Posiadał także zdolność wpływania na ludzkie sny. U Greków jednak, chociaż funkcje boskich opiekunów-pasterzy przypisywano aż kilku bogom $^{88}$, to zarówno epitet Hermesa Kplopópos (Niosacy baranka), jak i zachowane wizerunki boga niosącego baranka, wydają się wskazywać, że było to jedno z najważniejszych bóstw opiekujących się pasterzami i ich trzodami. Pasterską funkcję Hermesa ujawniają także inne z jego przydomków, takie jak: Epimeljos, Nomios czy Melosoos ,ten, który ratuje owce”. Ślady kultu boga Hermesa opiekuna trzód są najbardziej widoczne w Arkadii i Beocji, gdzie mieściły się zarówno świątynie boga Kriophoros, jak i jego posągi. W Attyce Hermesowi składano ofiary w grotach i jaskiniach, w których czczone były także nimfy. Najczęściej przyjmuje się, że ofiary te pasterze składali bóstwom związanym z naturą. My nie wykluczalibyśmy, że ofiary były składane przez panny młode przed zawarciem związku małżeńskiego lub po zaślubinach; czczono nimi boginki, opiekunki młodych dziewcząt i bóstwo, które towarzyszyło im w rytuale przejścia. Malarstwo wazowe ukazuje Hermesa m.in. z po-

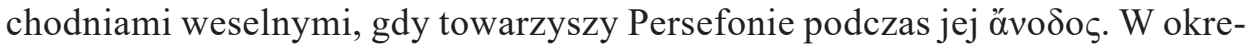
sie klasycznym i w epokach następnych związek tych bóstw jest widoczny m.in. na reliefach wotywnych, które przedstawiają Hermesa w towarzystwie nimf lub nimf i Pana ${ }^{89}$.

87 Cf. West 2007: 282-283.

${ }^{88}$ Byli nimi zarówno Hermes, Apollo, Pan czy Zeus. Cf. Stroszeck 2004: 232. http://www. isvroma.it/public/ pecus/stroszeck.pdf [data dostępu 5.09.2019].

${ }^{89} C f$. Laferrièr 2019: passim. 
Podobnie jak Pūsán, tak i Hermes był uznawany za Przewodnika dusz w dro-

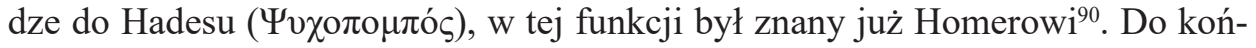
ca starożytności o człowieku zmarłym mówiono „Hermes go zabrał”"91. Podczas Anthesteriów, które były jednocześnie świętem Dionizosa-boga wina, jak i zmarłych, ważną rolę odgrywał także Hermes psychopompos. Odprowadzał dusze zmarłych, które podczas święta ,przechadzały się po mieście”, z powrotem do Hadesu. Wiele elementów tych uroczystości mogłoby wskazywać, że mamy do czynienia z obrzędami magicznymi, apotropaicznymi, a w istocie były to obrzędy kultowe, jakie miały miejsce podczas jednego z najważniejszych świąt religijnych starożytnych Greków. Dodajmy - uroczystości, które notowały kalendarze kultowe nie tylko w Attyce, ale również poza nią. Ateńczycy, przygotowując się do tego święta, smarowali swe domostwa smołą, aby zabezpieczyć je przed duchami. Podczas drugiego dnia Anthesteriów w czasie Choes, chłopcy, którzy brali udział w święcie, nosili amulety zabezpieczające je przed złem lub duchami. Trzeciego dnia Anthesteriów podczas Chytroi, Ateńczycy gotowali potrawę zwaną panspermia. Przygotowywanej potrawy nikt nie spożywał. Przebłagiwano za jej pomocą zarówno Hermesa i Dionizosa, jak i zmarłych. Po złożonej ofierze następowało wypędzanie duchów za pomocą stałej formuły - zaklęcia wypowiadanego w try-

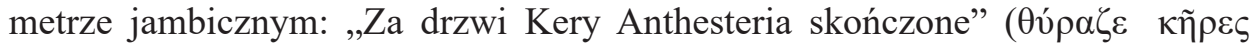

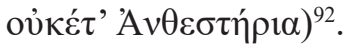

Podobnie jak Pūsán, tak i Hermes był uznawany za opiekuna wędrowców. Pobożni Grecy, mijając w drodze stosy kamieni poświęconych Hermesowi, które znaczyły szlaki wędrowne, dokładali do nich własny kamyk. Jako opiekun granic: pól, rozdroży, domów, był utożsamiany z kamieniami wyznaczającymi te granice. Jego moc tkwiła w kamieniu, który uosabiał boga, był rzeczą świętą, jemu poświęconą, obiektem sakralnym ${ }^{93}$. Jeszcze w IV w. p.n.e. Arystoteles w Metafizyce utrzymywał, że „Hermes jest w kamieniu”94. Droga, jaka wiodła od wyobrażeń boga w postaci prostego głazu, kopca kamieni do hermy - ,posągu boga" - w formie kamiennego lub drewnianego czworokątnego słupa zwężającego się ku dołowi, z wyobrażeniem fallusa, a w okresie późniejszym zakończonego także popiersiem lub rzeźbą głowy, to jedyne możliwe do zaobserwowania dążenie Greków, aby nadać swym bogom cechy „,bardziej ludzkie”; ale rzecz istotna, hermy nigdy nie przybrały postaci całkowicie antropomorficznej. Podejrzewamy, że stało się tak dlatego, iż moc Hermesa tkwiła w kamieniu, a głaz, kopczyk czy też herma, gdy już zostały poświęcone bogu, były uznawane za rzecz nietykalną, świętą. Gdy w roku 415 p.n.e. w Atenach dopuszczono się zniszczenia herm, które mieściły się przed świątyniami i w przedsionkach prywatnych domów, dewastację posągów

\footnotetext{
90 Cf. Kerényi 1993: passim.

Cf. Zieliński 1921: 26.

Cf. Faraone 2009: 232-233.

93 Obszerną dyskusję związane z tym teonimem prezentuje Skarbek-Kazanecki 2017: 22-25.

${ }^{94}$ Cf. 1002a, 1017b.
} 
boga uznano za czyn bezbożny, zły omen dla przygotowywanej wyprawy sycylijskiej, a ponadto za jawny spisek przeciwko demokracji. Sprawa hermokopidów wywołała w Atenach prawdziwe trzęsienie ziemi. Oskarżono i stracono wiele osób, wśród nich wiele niewinnych. Wielu, obawiając się oskarżenia o bezbożność, zbiegło za granicę. Imiona osób skazanych zostały zapisane na stelach, a ich majątek skonfiskowano.

Wraz z rozwojem cywilizacyjnym Hellenów Hermes opiekun wędrujących za stadami pasterzy, Hermes w kamieniu, który wyznaczał wędrowne szlaki, stał się opiekunem przebywających w drodze kupców, handlarzy, a także złodziei ${ }^{95}$. Jako wynalazca ćwiczeń gimnastycznych stał się patronem palestry i gimnazjonu. Wysoko cenili go mówcy i retorzy, uznając „biegłe w mowie bóstwo” za swojego boskiego opiekuna. Każdy z przedstawicieli wymienionych grup, mógł złożyć bogu ofiarę, czy to w którejś ze świątyń, czy też poza nią.

W okresie hellenistycznym i wiekach następnych stał się bóstwem synkretycznym, utożsamianym z Thotem lub Tehuti. Hermes Trismegistos, Hermes Po

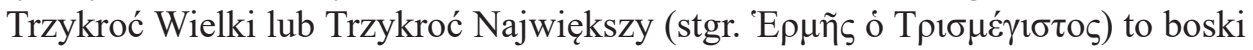
opiekun magii, wiedzy tajemnej i alchemii ${ }^{96}$. Od czasów bizantyńskich Hermesa Po Trzykroć Wielkiego uznawano za autora zbioru tekstów, który nosił tytuł Corpus Hermeticum, Pisma hermeneutyczne. Dzieło to obejmuje osiemnaście odrębnych rozpraw z różnych epok. Najstarsza z nich, zatytułowana Poimandres, powstała prawdopodobnie w II w n.e. Ostatnia, nosząca tytuł Asclepius, pochodzi z czasów Konstantyna Wielkiego, więc z IV wieku. Corpus Hermeticum to zbiór pism o charakterze filozoficznym, religijnym i teologicznym. Koncepcja bóstwa, jaka wyłania się z tych traktatów, ma swoje źródło tak w filozofii stoików, Platona, neoplatoników, jak i gnostyków. Hermes Trismegistos to bóg, który wtajemnicza w swe nauki jedynie nielicznych. Hermetyzm miał egalitarny charakter. W przypadku boga opisywanego w Corpus Hermeticum, trudno jest orzec, jaki istniał związek pomiędzy Trismegistosem, a bogiem Hermesem, jakiego znali i czcili starożytni Grecy ${ }^{97}$.

Apulejusz z Madaury, mag i poeta, człowiek na wskroś pobożny, „«poszukiwacz boga», pełen tęsknot mistycznych [...] podróżnik o nienasyconej ciekawości rzeczy świętych i uświęconych" "98, najprawdopodobniej był gorliwym wyznawcą i Hermesa psychopomposa, i Trismegistosa. W Apologii przyznawał, że posiadał drewnianą figurkę kultową Hermesa, z którą nigdy się nie rozstawał. W dni świąteczne modlił się do boga, palił kadzidła, spełniał ku jego czci libację i składał mu ofiary ${ }^{99}$. W tym samym utworze utrzymywał również, że bliski jest mu bóg

${ }^{95}$ Cf. Brown 1969: passim.

${ }^{9}$ Cf. Banek 2013: passim.

${ }^{97}$ Cf. Pawłowski 2002: 156.

${ }^{98}$ Cyt. za: Sękowski 1999: 7.

${ }_{99}$ Cf. Apulejusz z Madaury, Apologia, czyli w obronie własnej księga o magii, 61, 63 (Sękowski 1999: 250). 
(Basileus), pojmowany jako „Przyczyna, mózg i źródło początku, najwyższy rodziciel ducha, wieczny zbawiciel wszystkiego, co żyje, nieustanny twórca swojego świata [...] niepojęty nigdzie, nigdy i pod żadną postacią i dla tego przez niewielu wyobrażony, przez nikogo niewypowiedziany" ${ }^{100}$. Podobne rozważania o Stwórcy wszystkich rzeczy - Hermesie Po Trzykroć Wielkim, odnaleźć można w rozprawie zatytułowanej Asklepiusz, czyli rozmowa z Hermesem Trismegistosem, której autorstwo przypisywano Apulejuszowi ${ }^{101}$. W koncepcji boga przedstawionej przez autora tej rozprawy, bóg pojmowany jest jako Stwórca wszystkich rzeczy. Pobożność człowieka wyrażona wobec tak pojmowanego boga, powinna sprowadzać się jedynie do miłości i dziękczynnych modlitw.

Przeciwko Apulejuszowi wniesiono oskarżenie do sądu o uprawianie magii. Utrzymywano, że posłużył się czarami, aby zdobyć rękę Pudentilli, matki swojego przyjaciela. Rozprawie przewodniczył prokonsul Afryki, Maximus Claudius, przyjaciel cesarza i filozof stoicki. Proces miał miejsce w mieście Sabrata. Zarzuty wobec poety zostały oddalone. Apulejusz wygłosił w swojej obronie mowę, która zachowała się do naszych czasów pod nazwą Apologia, czyli w obronie własnej ksiega o magii. Dzieło to jest dla nas cennym źródłem, gdyż uświadamia nam, jak niewielka granica dzieliła religię od magii, w czasach starożytnych.

No, bo jeśli (co zresztą czytałem u bardzo wielu pisarzy) w języku greckim „mag” jest tym, czym u nas „kapłan”, cóż to wreszcie za zbrodnia być „kapłanem”, znać sposoby odprawiania świętych obrzędów, zasady składania ofiar, założenia różnych religii i mieć w tym wszystkim wiedzę i doświadczenie ${ }^{102}$. [...] magia, o która tak nierozsądnie oskarżacie, jest nauką miłą bogom nieśmiertelnym, pouczającą, jak ich czcić i szanować? Jest ona, rzecz jasna, święta, wie, co boskie [...] tylko tego uważają za maga, kto posiadł wspólny język z bogami nieśmiertelnymi i za pomocą jakiejś niewiarygodnej potęgi zaklęć potrafi zrobić wszystko, czego zapragnie $[\ldots]$.

Hermes, to z pewnością jedno z najważniejszych bóstw Greków czczonych zarówno podczas oficjalnych świąt poświęconych tylko temu bogu, jak i w trakcie rytuałów magicznych, ale, co należy podkreślić z całą mocą, nie jedyne.

Hekate była boginią czarów i czarownic, klucznicą świata podziemnego, ale także strażniczką najważniejszych punktów liminalnych w świecie żywych: rozdroży, portów, bram wiodących do miasta czy też domów. Co miesiąc Ateńczycy zanosili kolacje dla Trioditis. To ją przyzywały starożytne czarownice podczas swoich seansów, gdy zbierały magiczne zioła i sporządzały z nich swe phármaka. To jej imię było wymawiane podczas obrzędów magicznych i zapisywane na tabliczkach, które po spełnionym obrzędzie zakopywano bądź topiono w głębokich wodach ${ }^{103}$.

${ }^{100}$ Ibidem, 64.

101 Cf. Pawłowski 2002: 155-156.

102 Apulejusz z Madaury, Apologia, czyli w obronie własnej księga o magii, 25 (Sękowski 1999: 250).

${ }^{103} C f$. Rybowska 2015: 53-68. 
Demeter utożsamiana z Matką Ziemią była czczona jako dawczyni zboża, plonów rolnych i owoców, ale pojawia się równie często na tabliczkach magicznych jako adresatka próśb czy tez żądań zadośćuczynienia doznanym krzywdom. Podobnie rzecz wyglądała z jej córką Persefoną, która była władczynią świata pod-

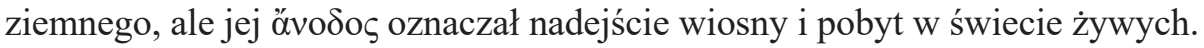

W książce poświęconej magii starożytnych Greków Collins słusznie zwraca

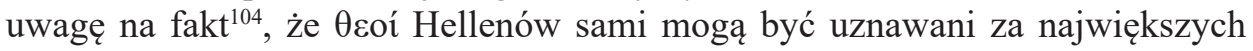
magów. Dysponowali bowiem nie tylko nadludzkimi mocami, ale także wiedzą tajemną, jaką zazwyczaj przypisuje się wielkim magom i czarodziejom. Jednym z atrybutów Hermesa była różdżka - kaduceusz, dzięki której był on w stanie sprowadzać sen. Persefona w świecie podziemnym odbierała ludziom pamięć. Przy pomocy phármaka lub jedynie sobie znanych obrzędów bogowie mogli zapewnić swoim wybrańcom nieśmiertelność, a przy pomocy tajemnych soków i magicznych roślin zamieniali ich w rośliny czy zwierzęta.

Zagadnienia, które poruszyliśmy w tym artykule, nie wyczerpują całości problematyki związanej z magią i religią starożytnych Greków. Cel, jaki postawiliśmy sobie w tej pracy był inny, analizowaliśmy w niej, na ile współcześnie tworzone definicje religii i magii, znajdują swoje potwierdzenie w przypadku tej konkretnej kultury.

Jednym z wyznaczników, przy pomocy którego starano się odróżnić religię od magii w różnych kulturach było to, jak pojmowano w nich bogów. Czy reprezentowali oni bliżej nieokreślonych daimones czy też byli oni pojmowani jako bóstwa o ściśle określonych kompetencjach. Tego typu wyróżnik jest całkowicie bezużyteczny w przypadku wielu kultur, w tym kultury Greków. Wspólne było przekonanie Hellenów, co do tego, że bóstwo może się objawić. Owa epifania - objawienie się bóstwa było możliwe zarówno w przypadku pojedynczego człowieka, jak i grupy ludzi. Grecy byli przekonani, że ,jakiś bóg” czy ,jakieś bóstwo” może przybrać dowolną formę. Wierzono również, że bogowie objawiali się czy też zjawiali podczas świat obchodzonych ku ich czci. Świątynia była uznawana za siedzibę boga, ale nie oznaczało to, że Grecy wierzyli, że bóg stale przebywa w poświęconych mu miejscach. Jak mogliśmy to zaobserwować na przykładzie kultu Hermesa, miejsc nad którymi bóstwo to sprawowało swą opiekę było co najmniej kilka. Niezmienne pozostawało w kulturze Greków przekonanie, że pomiędzy człowiekiem a bóstwem kontakt może być nawiązany jedynie w sposób pośredni. Ten brak możliwości bezpośredniego nawiązania kontaktu z bogami sprawiał, że tak duże znaczenie przypisywano wróżbiarstwu i kapłanom, którzy interpretowali znaki przesyłane od bogów, ponadto modlitwom i ofiarom. Magia podobnie jak religia była uznawana za rzecz świętą. Pojmowano ja w ten sam sposób jak religię, jako „służbę dla bogów". Pierwotne znaczenie słowa mágos oznaczało kapłana lub jakiegoś specjalistę od sacrum. Wieszczek, mag, kapłan to specjalista od sacrum i jednocześnie lekarz

104 Collins 2008: 27-30. 
(iatrós). Do specjalistów tych zwracano się z prośbą o poradę jak zaradzić złu, jakie spotykało poszczególnych ludzi lub całe społeczności.

Kolejną, wskazywaną przez współczesnych badaczy różnicą, jaka miała oddzielać religię od magii, były różne formy rytuału, jakie towarzyszyły różnym dziedzinom. To wyłącznie z magią miały być związane zaklęcia, klątwy, amulety, „pętanie” czy też „wiązanie”. Religia miała pozostawać wolna od tego typu praktyk. W przypadku starożytnych Greków zaklęcia, klątwy, amulety i „wiązanie” za pomocą przysiąg były nieodłączną częścią i religii, i magii. Klątwa była forma wezwania bóstwa do wyrażenia gniewu wobec tych, którzy wyrządzili komuś krzywdę. Określała zakres zemsty. Amulety odgrywały równie ważną rolę w greckiej medycynie w kulcie bogów, jak i w magii. We współczesnych badaniach mocno akcentuje się również znaczenie modlitwy jako czynnika umożliwiającego odróżnienie sfery religii od magii, ale, co należy podkreślić i ten wyróżnik nie może być przyjęty bez żadnych zastrzeżeń. Inną postać miały modlitwy Greków spisywane na użytek oficjalnych praktyk religijnych, związanych z religią poszczególnych poleis, a jeszcze inną prośby do bogów kierowane w chwilach kryzysu, bezpośredniego zagrożenia życia. Nawet na katádesmoi możemy zaobserwować prośby kierowane do bogów, które były zbliżone w swej formie do euché (defixio in fures odnalezione na wyspie Amorgos).

O wspólnych rysach tak religii, jak i magii w starożytnej Grecji świadczy również fakt, że w starożytnej Helladzie nie wytaczano procesów o bezbożność za uprawianie magii. Karano za „czarownictwo”, a więc posługiwanie się phármaka, truciznami, które miały pozbawić życia drugiego człowieka.

Przyjmujemy, podobnie jak Wierciński, że magia i religia przynależą , do kultury duchowej, która obejmuje wszystkie te czynności i wytwory, które uczestniczą w zaspakajaniu specyficznych ludzkich potrzeb" ${ }^{105}$. Możemy jedynie dodać, że w przypadku Hellenów potrzeby te były zaspakajane w równym stopniu i w oparciu o religię, i magię. Obie dziedziny przenikały się i uzupełniały.

\section{Bibliografia}

\section{Teksty źródłowe}

Allen, T.W. (red.) (1917-1919). Homeri Odyssea: Homeri Opera, t. 3-4. Oxford: Clarendon Press. Homolle, T. (1901). "Inscriptions d'Amorgos". Bulletin de Correspondance Hellénique 25. 412-430. Krąpiec, A. et al. (1996). Arystoteles, Metafizyka, t. 1. Lublin: KUL.

Munro, D.B., Allen, T.W. (red.) (1920). Homeri Ilias. Homeri Opera, t. 1-2. Oxford: Clarendon Press. Murray, G. (red.) (1902-1909). Euripidis Fabulae, t. I-III. Oxford: Clarendon Press. 


\section{Przekłady}

Bednarczyk, A. (1992). „System filozoficzno-lekarski Galena (130-200): Pojęcie duszy.” Analecta $1 / 2.81-121$.

Biernat, P. (2017). Platon, Państwo. W: P. Biernat (red.). Ofiara w Grecji starożytnej w świetle danych filologicznych. Corpus Platonicum, Corpus Hippocraticum. Warszawa: Wydawnictwo Naukowe Sub Lupa. 127-147.

Gajda-Krynicka, J. (1993). Jamblich, O życiu pitagorejskim. Wrocław: Wydawnictwo Epsilon.

Głombiowski, K. et al. (2014). Ksenofont, Wychowanie Cyrusa. Wrocław: ISKŚiO UWr.

Hammer, S. (1954). Herodot, Dzieje. Warszawa: Czytelnik.

Jeżewska, K. (1999). Homer, Iliada. Warszawa: Prószyński i S-ka.

Kornatowski, W. (1960). Cyceron, O naturze bogów; O wróżbiarstwie; O przeznaczeniu. Kraków: Państwowe Wydawnictwo Naukowe.

Krońska, I. et al. (1982). Diogenes Laertios, Żywoty i poglady sławnych filozofów. Warszawa: Państwowe Wydawnictwo Naukowe.

Leśniak, K. (1972). Materialiści greccy w epoce przedsokratejskiej. Warszawa: Wiedza Powszechna.

Sękowski, J. (1999). Apologia czyli w obronie własnej. Księga o magii. Warszawa: Prószyński i ska.

Wesoły, M. (2008). O świętej chorobie. W: Hippokrates. Wybór pism, t. 1. Warszawa: Prószyński i ska.

Witwicki, W. (2006). Platon, Dialogi. Warszawa: Unia Wydawnicza „Verum”.

Wypustek, A. (1997). „[Inskrypcja z Amorgos] Grecko-rzymska literatura magiczna... jako literatura”. Poznańskie Studia Polonistyczne 24. 251.

\section{Monografie i artykuly}

Angutek, D. (2006). „Idea ruchu u milezyjczyków i Heraklita - hipoteza wyjaśniająca”. Nowa Krytyka. Czasopismo Filozoficzne, http://www.nowakrytyka.pl/spip.php?article303 [data dostępu 8.11.2015].

Audollent, A. (1967). Defixionum tabellae, quotquot innotuerunt tam in Graecis Orientis quam in totius Occidentis partibus praeter Atticas in Corpore Inscriptionum Atticarum editas. Frankfurt: Minerwa.

Banek, K. (2013). W kręgu Hermesa Trismegistosa. Warszawa: Okultura.

Beerden, K. (2013). Worlds Full of Sings: Ancient Greek Divination in Context. Leiden: Brill.

Biernat, P. (2013). „«Skoro tak czynią, czyż nie są straszni w oczach bogów?» - wędrowni specjaliści rytualni w oczach autora De morbo sacro". Iuvenilia Philologorum Cracoviensium, t. VI, Źródła Humanistyki Europejskiej 6. 27-41.

Bremmer, J.N. (1999). „The Birth of Term «Magic»”. Zeitschrift für Papyrologie und Epigraphik. 126. $1-12$.

Bremmer, J.N. (2004). Divination. W: Brill's New Pauly: Encyclopaedia of the Ancient World 4. 569-574. Bremmer, J.N. (2010). "Manteis, Magic, Mysteries and Mythography". Kernos 23. 13-35.

Bremmer, J.N. (2016). Ancient Necromancy: Fact or Fiction? W: Bielawski, K. (red.). Mantic Perspectives. Oracles, Prophecy and Performance. Gardzienice-Lublin-Warszawa: Ośrodek Praktyk Teatralnych „Gardzienice”, Wydział Artes Liberales UW. 119-141.

Brown, N.O. (1969). Hermes the Thief. The Evolution of a Myth. New York: Vintage Books.

Buchowski, M. (1986). Magia. Jej funkcje i struktura. Poznań: Wydawnictwo Naukowe UAM.

Buchowski, M. (2005). "Odmienność magii i religii". W drodze 383/7. 57-67.

Burkert, W. (2005). Divination: Mantik in Griechenland. W: Thesaurus Cultus et Rituum Antiquorum III. Los Angeles: The J. Paul Getty Museum. 1-51. 
Collins, D. (2008). Magic in the Ancient Greek World. Malden, MA: Blackwell.

Cotter, W. (1999). Miracles in Greco-Roman Antiquity: A Sourcebook. New York: Routledge.

Cunningham, G. (1999). Religion and Magic. Approaches and Theories. Edinburgh: Edinburgh University Press.

Dickie, M.W. (2003). Magic and Magicians in the Greco-Roman World. London-New York: Routlege.

Dufault, O. (2017). Who wrote Greek Curse Tablets? W: Evans, R. (red.). Prophets and Profits. Ancient Divination and Reception. London-New York: Routlege. 1-20.

Eidinow, E. (2007). Oracles, Curses, and Risk among the Ancient Greeks. Oxford: Oxford University Press.

Faraone, C.A. (1991). The Agonistic Context of Early Greek Binding Spells. W: Faraone, C.A., Obink, D. (red.). Magika Hiera: Ancient Greek Magic and Religion. Oxford: Oxford University Press. 3-32.

Faraone, C.A. (2009). „Stopping Evil, Pain, Anger, and Blood: The Ancient Greek Tradition of Protective Iambic Incantations". Greek, Roman and Byzantine Studies 49/2. 227-255.

Gager, J.G. (1992). Curse Tablets and Binding Spells from the Ancient World. New York-Oxford: Oxford University Press.

Gajda, J. (1986). Prawo natury i umowa społeczna w filozofii przedsokratejskiej. Wrocław: Wydawnictwo UWr.

Garcia-Teijeiro, M. (1993). „Religion and Magic”. Kernos 6. 123-138.

Gordon, R. (1987). „Aelian's Peony: the Location of Magic in Graeco-Roman Tradition”. Comparativ Criticism 9. 59-95.

Halliday, W.R. (1913). Greek Divination: a Study of its Methods and Principles. London: Macmillan.

Hubert, H., Mauss, M. (1973). Zarys ogólnej teorii magii. Przeł. M. Król. W: Mauss, M. Socjologia i antropologia. Przeł. M. Król, K. Pomian, J. Szacki. Warszawa: Państwowe Wydawnictwo Naukowe.

Jastrzębski, M. (2014). Wczesna filozofia grecka jako archaiczna droga do nieśmiertelności. Próba rekonstrukcji. Białystok: Niepaństwowa Wyższa Szkoła Pedagogiczna.

Jerzak-Gierszowska, T. (1995). Religia a magia. Klasyczne koncepcje antropologiczne. Poznań: Wydawnictwo Fundacji Humaniora.

Johnston, S.I., Struck, P.T. (red.) (2005). Mantikê: Studies in Ancient Divination. Leiden-Boston: Brill.

Jong de, A.F. (1997). Traditions of the Magi: Zoroastrianism in Greek and Latin Literature. LeidenNew York-Cologne: Brill.

Kerényi, K. (1993). Hermes przewodnik dusz. Przeł. J. Prokopiuk. Warszawa: Wydawnictwo Sen.

Kracik, J. (2012). Chrześcijaństwo kontra magia. Historyczne perypetie. Kraków: Wydawnictwo M. Krokiewicz, A. (1947). Studia orfickie. Warszawa: Biblioteka Meandra, 3.

Laferrièr, C.M. (2019). Hermes among Pan and Nymphs on Fourth - Century Votive Reliefs. W: Strauss, J., Miller, J. (red.). Tracking Hermes, Pursuing Mercury. Oxford: Oxford University Press. 31-48.

Lengauer, W. (1994). Religijność starożytnych Greków. Warszawa: Państwowe Wydawnictwo Naukowe.

Lengauer, W.; Stebnicka, K. (1994). „Empedokles i jego «Katharmoi»”. Ars Regia 1/6. 18-30.

Lévi-Strauss, C. (2000). Antropologia strukturalna. Przeł. K. Pomian. Warszawa: Wydawnictwo KR. Lévi-Strauss, C. (2001). Myśl nieoswojona. Przeł. A. Zajączkowski. Warszawa: Wydawnictwo KR. Luck, G. (1985). Arcana Mundi. Magic and Occult in the Greek and Roman Worlds. Baltimore: John Hopkins University Press.

Ługiewicz, A. (2001). „Antyczna magia i religia”. Przeglad Religioznawczy 2. 3-18.

Malinowski, B. (1900). Dzieła, t. 7. Mit, magia, religia. Przeł. B. Leś, D. Praszałowicz. Warszawa: Państwowe Wydawnictwo Naukowe. 
Ogden, D. (2001). Greek and Roman Necromancy. Princeton: Princeton University Press.

Oświecimski, S. (1989). Zeus daje tylko znak Apollo wieszczy osobiście. Starożytne wróżbiarstwo greckie. Wrocław: Wydawnictwo Zakładu Narodowego im. Ossolińskich.

Parker, R. (1985). Pleasing Thighs: Reciprocity in Greek Religion. W: Gill, C., Postlethwaite N., Seaford R. (red.). Reciprocity in Ancient Greece. Oxford: Clarendon Press. 105-125.

Parker, R. (1995). Greek States and Greek Oracles. W: Cartledge, P.A., Harvey, F.D. (red.). Crux: Essays Presented to G.E.M. de Ste. Croix on his 75th Birthday. History of Political Thought VI 1/2. Sidmouth: Duckworth. 298-326.

Parker, R. (1996). Miasma. Pollution and Purification in Early Greek Religion. Oxford: Oxford University Press.

Pawłowski, K. (2002). Apulejusz z Madaury, O bogu Sokratesa; O Platonie i jego nauce; O świecie oraz Pseudo-Apulejusz, Asklepiusz czyli Rozmowa z Hermesem Trismegistosem. Warszawa: Wydawnictwo Naukwe PWN.

Pettersson, O. (1957). "Magic - Religion: Some Marginal Notes to an Old Problem". Ethnos. Journal of Anthropology 22 (3/4). 109-119.

Posacki, A. (2009). Okultyzm, magia, demonologia. Kraków: Wydawnictwo M.

Przybyłek, M. (2011). „Sanktuarium Asklepiosa w Epidauros”. Collectanea Philologica 14. 105118.

Rybowska, J. (2014). Dionizos. Agathos Daimon. Kraków-Łódź: Tyniec. Wydawnictwo Benedyktynów, Seria: Homini, Wydawnictwo Uniwersytetu Łódzkiego.

Rybowska, J. (2015). Hekate - bogini o wielu twarzach. W: Pietrzak-Thébault, J., Cybulski, Ł. (red.). Czary, alchemia, opętanie w kulturze na przestrzeni stuleci. Studia przypadków. Warszawa: Wydawnictwo UKSW.

Rybowska, J. (2017). Zbożność i bezbożność w kulturze Greków. Łódź: Wydawnictwo Uniwersytetu Łódzkiego.

Sieradzan, J. (2005). „O względności pojęć «magii i religii»”. Lud 89. 13-50.

Sieradzan, J. (2011). Sokrates magos. Autsajderstwo, magia, charyzma w kontekście antropologii symbolicznej Viktora Turnera. Warszawa: ENTEIA. Wydawnictwo Psychologii i Kultury.

Skarbek-Kazanecki, J. (2017). „Grecki bóg Hermes i bogini wedyjska Sarama w aspekcie porównawczym”. Collectanea Philologica XX. 22-25.

Stroszeck, J. (2004) Divine Protection for Shepherd and Sheep Apollon, Hermes, Pan and their Christian Counter St. Mamas, St. Themstocles and St. Modestos. PECUS. Red. B. Santillo Frizell, Rome: The Swedish Institute in Rome. Projects and Seminars, 1. http://www.isvroma.it/public/ pecus/stroszeck.pdf. [data dostępu 11.09.2019].

Szczerba, W. (2014). Koncepcja wiecznego powrotu. Toruń: Wydawnictwo Uniwersytetu Mikołaja Kopernika.

Szyjewski, A. (2008). Etnologia religii. Kraków: Zakład Wydawniczy Nomos.

Tambiah, S.J. (2007). Magia, nauka, religia a zakres racjonalności. Kraków: Wydawnictwo Uniwersytetu Jagiellońskiego.

Trzcionkowski, L. (2005). Wieszczacy głos Orfeusza. W: Bielawski K. (red.). Perspektywy mantyczne: wyrocznie, proroctwa i performatyka. Gardzienice-Lublin-Warszawa: Ośrodek Praktyk Teatralnych „Gardzienice”. Wydział Artes Liberales UW. 145-170.

Trzcionkowski, L. (2013). Bios Thanatos Bios. Semiofory orfickie z Olbii i kultura polis. Warszawa: Wydawnictwo Naukowe Sub Lupa.

Versnel H.S. (1981). Religious Mentality in Ancient Prayer. W: Versnel H.S. (red.). Faith, Hope and Worship: Aspects of Religious Mentality in the Ancient Word. Leiden: Brill. 1-64.

Versnel H.S. (1991). "Some Reflections on the Relationship Magic - Religion". Numen 38. 177-197.

Versnel H.S. (2002). Writing Mortals and Reading Gods: Appeal to the Gods as a Duel Strategy for Social Control. W: Cohen D. (red.). Demokratie, Recht und soziale Kontrolle im klassischen Athen. München: Oldenburg. 37-76. 
West, M.L. (2007). Indo-European Poetry and Myth. Oxford: Oxford University Press. Wierciński, A. (2000). Magia i religia. Szkice z antropologii religii. Kraków: Nomos.

Wiszowata, M. (2012). „Antyczne tradycje o życiu Hippokratesa”. Wratislaviensium Studia Classica $\mathrm{I} / 32.151-179$.

Wypustek, A. (2001). Magia antyczna. Wrocław: Wydawnictwo Zakładu Narodowego im. Ossolińskich.

Zieliński, T. (1920). Hermes Trismegistos. Studjum z cyklu: Wspótzawodnicy chrześcijaństwa. Zamość: Zygmunt Pomarański i Spółka.

Zimoń, H. (2011). „Terminy «magia» i «czarownictwo» w świetle badań etnologicznych i religioznawczych”. Roczniki Teologii Fundamentalnej i Religiologii 3/58. 167-197.

dr hab. Joanna Rybowska (Uniwersytet Łódzki) - Assistant Professor at the Chair of Hellenistic and Religious Studies in the Department of Classical Philology University of Lodz. As the president of the Łódź Circle of the Polish Philological Society, and later renamed as the Łódź Branch of the Polish Philological Society as well as a member of the board of the Polish Philological Society, she coordinates the activities of the branch in Łódź, but also cooperates with scholars from other research centres. In 2019, she obtained her habilitation degree on the basis of her monograph Piety and Impiety in Ancient Culture. The monograph presents a broad discussion on the meaning of religion and its place in the culture of ancient Greeks; it analyses various testimonies featuring the mutual relations between men and the gods and is an attempt to explain the development of these relations, their perception and description.

e-mail: joannarybowska@yahoo.pl 